\title{
Indonesia: Report on Observance of Standards and Codes- Fiscal Transparency Module
}

This Report on the Observance of Standards and Codes on Fiscal Transparency for Indonesia was prepared by a staff team of the International Monetary Fund as background documentation for the periodic consultation with the member country. It is based on the information available at the time it was completed on July 7, 2006. The views expressed in this document are those of the staff team and do not necessarily reflect the views of the government of Indonesia or the Executive Board of the IMF.

The policy of publication of staff reports and other documents by the IMF allows for the deletion of market-sensitive information.

To assist the IMF in evaluating the publication policy, reader comments are invited and may be sent by e-mail to publicationpolicy@imf.org.

Copies of this report are available to the public from

International Monetary Fund • Publication Services

700 19th Street, N.W. • Washington, D.C. 20431

Telephone: (202) 6237430 • Telefax: (202) 6237201

E-mail: publications@imf.org • Internet: http://www.imf.org

Price: $\$ 15.00$ a copy

\section{International Monetary Fund Washington, D.C.}





\title{
INTERNATIONAL MONETARY FUND
}

\section{INDONESIA \\ Report on the Observance of Standards and Codes (ROSC) Fiscal Transparency Module}

\author{
Prepared by Fiscal Affairs Department \\ Approved by David Burton and Teresa Ter-Minassian
}

July 7, 2006

\section{EXECUTIVE SUMMARY}

This report provides an assessment of fiscal transparency practices in relation to the requirements of the IMF Code of Good Practices on Fiscal Transparency and is based on discussions with the authorities and other organizations, the authorities' response to the IMF fiscal transparency questionnaire, and other sources of information. The IMF Manual on Fiscal Transparency (http://www.imf.org/external/np/fad/trans/manual/) should be consulted for further explanation of the terms and concepts discussed in this report.

Indonesia has taken impressive steps in recent years to establish a sound legal and administrative system to improve transparency. Enactment in 2003-2004 of the State Finance Law, the Treasury Law, and the State Audit Law, together with the steps being taken to implement them, have established a strategic basis for fiscal management reform. However, much remains to be done to extend these gains throughout general government.

The new laws for financial management are major steps towards improving the clarity of roles and responsibilities, although significant quasi-fiscal and extrabudgetary activities are not covered in the fiscal data. Progress in treasury reforms and improving accounting are strengthening the open budget preparation, execution, and reporting process. However, coverage of explicit and implicit fiscal risks is not comprehensive, and the internal audit function is in need of strengthening and rationalization. Delays in the subnational reporting system is an area of weakness that needs continuing coordinated action.

Central government budget and accounts documents achieve a good practice standard for the public availability of information. The Government Financial Statement for 2004 is an important step forward, while the lack of reporting on off-budget activity is the main area of weakness.

Public disclosure of oil revenue flows would also improve transparency. In terms of assurances of integrity, the independent status of the supreme audit institution, and the establishment of the AntiCorruption Commission represent a good institutional basis, which should be strengthened.

The authorities are taking action to address the various weaknesses. The report suggests a two part strategy: first, to deepen reforms of the central government budgetary sector; and, second, to widen the process of reform to all of general government. Priorities in the first area are (i) to strengthen technical capacity for fiscal policy formulation; (ii) to improve budget disclosure practices; and (iii) to strengthen and rationalize the key fiscal integrity institutions.

The second part of the strategy is more difficult and longer term, but it should be initiated strongly now. The two key elements are (i) promoting transparent practices at a regional level and between the regions and central government; and (ii) incorporating all extrabudgetary activity in the budget — or in another relevant sector of the economy. 


\section{CONTENTS}

I. Detailed Description of Practice.........................................................................

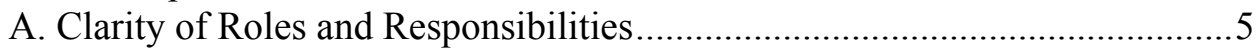

B. Open Budget Preparation, Execution, and Reporting ................................20

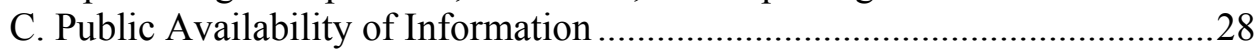

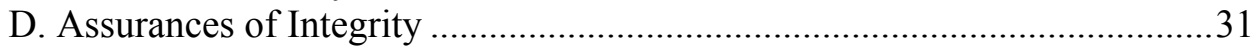

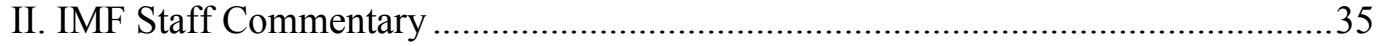

A. Deepening Reforms in the Central Government Budgetary Sector ..............35

B. Toward Comprehensive General Government Transparency ......................40

Table

1. Indonesia: Central Government Operations 2003-04 .............................................

Boxes

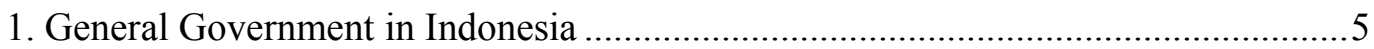

2. Revenue Sharing and Central Government Transfers to Local Governments...........15

3. The Central Government Budget Preparation Process ...........................................21

Appendix Table

1. Public Availability of Information-A Summary ................................................42 


\section{Abbreviations}

BAPEKKI

BAPPENAS

BAWASDA

BI

BPK

BPKP

BPMIGAS

BPHMIGAS

BPS

DAK

DAU

DG

DIPA

DPD

DPR

FITRA

FPO

GAFS

GFS

GFSM

IG

KADIN

KPK

KPPN

KUP Law

MOEMR

MOF

MOHA

MPR

MSOE

MTEF

NPL

PERTAMINA

PLN
Agency for Economic and Financial Research and International Cooperation

National Development Planning Agency

Provincial Internal Audit Authority

Bank of Indonesia

http://www.bi.go.id/web/en

Supreme Audit Institution

http://www.bpk.go.id

Financial and Development Supervisory Agency

http://www.bpkp.go.id

Oil and Gas Regulatory Authority [upstream]

http://www.bpmigas.com/ENGLISH/index.htm

Oil and Gas Regulatory Authority [downstream]

http://www.bphmigas.go.id/

National Statistics Office

http://www.bps.go.id/index.shtml

Special Allocation Grant

General Grant

Directorate General

Budget Implementation Documents

Regional Representative Council

House of Representatives

http://www.dpr.go.id

Indonesian Forum for Budget Transparency

Fiscal Policy Office

Government Annual Financial Statement

Government Finance Statistics

Government Finance Statistics Manual

Inspectorate General

Indonesian Chamber of Commerce and Industry

http://www.kadin.indonesia.or.id

Anti-Corruption Commission

State Treasury Service Office

Law on General Provisions and Tax Procedures

Ministry of Energy and Mineral Resources

http://www.esdm.go.id

Ministry of Finance

http://www.depkeu.go.id

Ministry of Home Affairs

People's Consultative Assembly

Ministry of State-Owned Enterprises

Medium-Term Expenditure Framework

NonPerforming Loan

State-Owned Oil Company

http://www.pertamina.com

State-Owned Electricity Company

http://www.pln.co.id/english 


$\begin{array}{ll}\text { PPP } & \text { Public Private Partnerships } \\ \text { PSC } & \text { Production Sharing Contract } \\ \text { PSO } & \text { Public Service Obligations } \\ \text { QFA } & \text { Quasi-Fiscal Activities } \\ \text { RDA } & \text { Regional Development Fund } \\ \text { RDI } & \text { Investment Funds [for onlending to enterprises] } \\ \text { RKA-KL } & \text { Work plan and budget of a central government ministry or institution } \\ \text { ROSC } & \text { Reports on the Observance of Standards and Codes } \\ \text { SOE } & \text { State-Owned Enterprise } \\ \text { TIN } & \text { Taxpayer Identification Number } \\ \text { TNI } & \text { Indonesian Armed Forces } \\ \text { TSA } & \text { Treasury Single Account } \\ \text { VAT } & \text { Value Added Tax }\end{array}$




\section{Detailed Description of Practice ${ }^{1}$}

\section{A. Clarity of Roles and Responsibilities}

\section{$\underline{\text { Definition of Government Activities }}$}

\section{General government is conceptually consistent with Government Finance Statistics (GFS) principles, but its coverage is incomplete.

The units of general government, and estimates of each subsector as a share of GDP, are shown in Box 1. Budgetary central government is defined consistently with GFS principles. However, a large range of extrabudgetary activities are carried out through nontax revenue or by ministry foundations and cooperatives (see discussion in paragraphs 3-4 below). Some aspects of these activities are of a governmental service nature. Data from the budgetary sector of subnational governments is not yet reported or consolidated for general government reporting comprehensively or in a timely way.

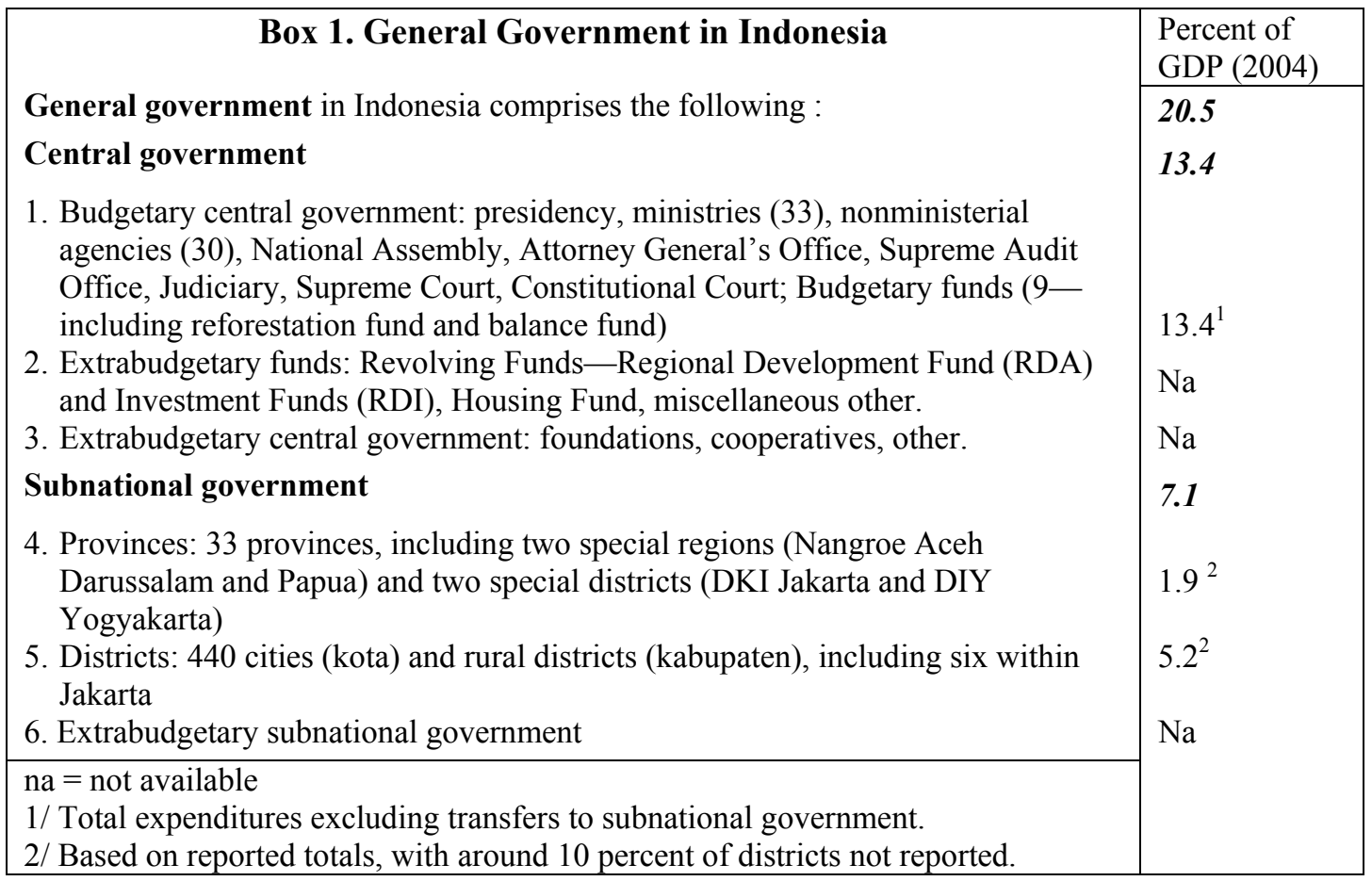

\footnotetext{
${ }^{1}$ This report was prepared by a Fiscal Affairs Department (FAD) team comprising Messrs. J. Davis (mission chief), I. Lienert, and A. Mati (all FAD) and W. Allan, P. Desai, and K. Meyers (consultants).

Messrs. S. Schwartz and A. Morales (IMF Resident Representatives) participated in many meetings and provided support. World Bank and Asian Development Bank (ADB) staff also attended a number of meetings, and the report draws on work by these institutions in several key areas. Discussions with the authorities, under the direction of the Minister of Finance, Mrs. Sri Mulyani Indrawati were open and frank. Meetings were coordinated by Messrs. Anggito and Maurin (both BAPEKKI), and the mission met with senior representatives of the following public and private sector organizations: BAPEKKI, BAPPENAS, BI, BPHMIGAS, BPK, BPKP, BPMIGAS, BPS, British Petroleum, DG TAX, DPR (Commission XI), FITRA, Garuda, Indonesia Petroleum Association, KADIN, Ministry of Defense, MOEMR, MOF, MOHA, MSOE, Pertamina, PLN, PricewaterhouseCoopers, and Jogjakarta province.
} 


\section{Budgetary central government includes earmarked and extrabudgetary funds; the housing fund is not integrated with the budget. \\ 1.1.1/1.1.3}

The main earmarked budget fund is the reforestation fund, which receives forestry fees, applies these to reforestation and related activities, and is now under budget authority. Regulation 35/2002 allows this fund to provide loans, although this element is not yet operational. Its receipts are deposited in the main treasury operational account at the Bank of Indonesia (BI) and then transferred to the reforestation account. The Investment Fund (RDI) and the Regional Development Fund (RDA) are revolving funds set up as vehicles for managing externally-financed government loans to State-Owned Enterprises (SOEs) and regional/local governments. Their transactions are now included in the budget and discussed in Parliament. Balances in RDA accounts may be re-lent to SOEs or local governments (a practice that has now ceased for RDI). The Government Annual Financial Statement (GAFS) for the 2004 accounts, records gross inflows and outflows and balances. ${ }^{2}$ The fund accounts, however, do not identify principal repayments, interest and penalties (for late payment) and arrears on on-lending (which are substantial). The housing fund, created in 1993, is entirely off-budget and not recorded in government accounts. The fund is financed by compulsory monthly salary deductions from civil servants, which can be used for a down payment on house purchases or renovations or can be withdrawn on retirement as a lump sum (without interest). Its policy status is unclear; while it could be interpreted as a social security scheme, it is not reported as such. ${ }^{3}$ The government is currently deciding on the housing fund's future status.

\section{Foundations and cooperatives are widespread and their extrabudgetary activities are not covered by general government statistics, although some steps are being taken to address this issue.

A number of foundations and cooperatives use government assets and raise funds from the public. Such entities are controlled by different government institutions and line ministries and operate at both national and regional level. The role of these entities has not been fully defined, nor have standard accountability and reporting procedures been followed, making it difficult to estimate the extent and nature of their activities. ${ }^{4}$ Many have characteristics that would require their inclusion in general government, as it is well-established that state assets and personnel are directly used. Foundations are also widely used as a means of supplementing line ministries' budgets, particularly those of the Indonesian Armed Forces (TNI) and police, but also reportedly for other ministries. They also provide governmental social services funded by what would normally be regarded as nontax revenues. Encouraging steps are being taken to implement Regulation 34/2004 stating that all TNI businesses must

\footnotetext{
${ }^{2}$ In 2004, the GAFS balance sheet recorded net assets for the revolving funds, but details were not included in the notes to the accounts.

${ }^{3}$ The (growing) deposits of the housing fund, which are held in commercial banks, provide a lending base and gives benefits to the general public, which constitutes a quasi-fiscal activity.

${ }^{4}$ Law 16/2001 regarding Foundations prescribes governance structures and financial reporting requirements. Inspection is authorized, but only if an unlawful act is suspected and it is under a court order (Article 53).
} 
be transferred to the government. ${ }^{5}$ These efforts are led by an interministerial commission, ${ }^{6}$ which is to conduct an inventory of all TNI businesses, ${ }^{7}$ followed by an external audit. The main objectives of the review are to define the entity functions and to initiate a program of reform that would: (a) include them in the budget; (b) establish a public corporation; or (c) dispose of the assets. ${ }^{8}$ The current reform efforts do not include police foundations.

\section{Government holdings of fully-owned corporations and equity are extensive;} a framework for corporate governance is being established.

As of August 2005, there were 158 state-owned enterprises (SOEs), of which 17 have minority government ownership. ${ }^{9}$ These enterprises are spread over 37 business sectors and vary in size from large monopolies and infrastructure enterprises to relatively small service companies. Banks and financial institutions represent 50 percent of total public assets (or about Rp 597 trillion as of end-2004 (audited)) followed by companies in the energy sector, such as PLN (the state-owned electricity company) and Pertamina (the state-owned oil company). ${ }^{10}$ Law 19/2003 on State-Owned Enterprises provides a sound structure for a good corporate environment, which is being progressively implemented. ${ }^{11}$ Dividends and profit transfers are expected to be paid one month after the end of the shareholders' meetings. ${ }^{12}$ Profit transfers from certain SOEs, notably Pertamina, are sometimes delayed as the government or other state-owned enterprises may not have compensated them for services rendered or goods sold (see discussion of Public Service Obligations (PSOs) below).

\footnotetext{
${ }^{5}$ Law 34/2004 on the TNI requires that the military should be funded entirely by the state through the budget (restating a provision already included in an earlier law, Law 3/2002 on defense).

${ }^{6}$ Chaired by the secretary-general of the ministry of state-owned enterprises (MSOE) and including the secretary-generals of the ministries of justice, finance and defense.

${ }^{7}$ There have been 219 businesses identified so far, but more foundations and cooperatives may be found.

${ }^{8}$ The commission is awaiting a presidential decree that would allow the transformation of military foundations into public enterprises or a sell-off of its assets. The commission is envisaging the creation of an institution that will help in transferring the foundations' assets (as was done by the Indonesian Bank Restructuring Agency during the banking crisis).
}

${ }^{9}$ GAFS 2004, records a value of Rp 395.7 trillion for central government state equity, while MSOE reports Rp 388.6 trillion.

${ }^{10}$ The size of the portfolio could be understated as some SOEs are excluded. Government shares vary from 15 percent to 100 percent of total equity. More than 90 percent of assets, equity and net income are held by the 22 largest SOEs.

${ }^{11}$ Law 19/2003 includes provisions regarding rules of conduct for conflicts of interest of directors or commissioners, requirements for a supervisory unit, regulations on audit committees, and compulsory audits of the annual financial statements of SOEs. Steps have been taken to remove directors where policy or regulatory responsibilities created a clear conflict of interest. However, audits of SOEs are not always produced and are sometimes delayed (e.g., Pertamina's financial statements for 2004). The government does not explicitly set wages for nonfinancial public enterprises nor affect hiring decisions by the board of directors.

${ }^{12}$ Profit transfers increased to Rp 12.8 trillion in 2005, up from Rp 9.8 trillion in 2004. These are expected to significantly increase in 2006 to Rp 23.2 trillion, reflecting higher profit transfers from Pertamina. Pertamina provides about two-thirds of SOE profit transfers and dividends received by the central government. 


\section{Financial data are regularly reported to the ministry of state-owned enterprises, but consolidated data are not widely available and analysis is limited.

Financial statements on SOEs' performance have to be submitted quarterly to the MSOE and to the appropriate sectoral ministry to which its activities belong. This information is not routinely distributed or used by the Ministry of Finance (MOF) in fiscal analysis. The MSOE has not yet developed a strong analytical overview of performance of the sector. The lack of analysis limits the government's ability to assess contingent liabilities and fiscal risks that may arise from SOEs.

\section{The legal framework for privatization is clear, although its implementation requires clarification.

The SOE law defines in broad terms the principles under which privatization is to be conducted..$^{13}$ It also defines the privatization process, including the establishment of a privatization committee, and use of the selection criteria defined in the law, as well as the process of making payments to the budget. Implementation of the privatization program has stalled, in part because of conflicts in laws initiated separately by the MOF and the MSOE. ${ }^{14}$ The budget privatization target for 2005 was not achieved, as no SOE was privatized. ${ }^{15}$ While the authorities advise that these entities are to be privatized in 2006, implementation of the overall program remains unclear.

Government relations with nonfinancial public corporations and the private sector

\section{Public nonfinancial corporations carry out significant quasi-fiscal activities (QFAs). ${ }^{16}$}

Services by Pertamina and PLN are provided at government-determined below-market prices. Much of this activity is explicitly subsidized by the budget. ${ }^{17}$ This formal designation of public service obligations to be carried out by enterprises and their explicit funding in the budget are good steps toward transparency. However, the general treatment of PSOs does not yet represent a carefully designed policy and few of them are accurately costed. In a number

\footnotetext{
${ }^{13}$ SOEs that cannot be privatized include sectors related to defense and security, and those designated as special public interest by the government.

${ }^{14}$ Article 82 of Law 19/2003 and Ministerial Decree 33 only require that parliament be consulted, whereas the State Finance Law 17/2001 requires parliamentary approval.

${ }^{15}$ Privatization targets in 2002-04 were met. The main sales route was through initial public offerings and strategic partnerships.

16 An activity is designated as a QFA if it is of a fiscal nature but financed by a public (or in some cases private) corporation rather than by the budget. PSOs of state enterprises are generally explicitly financed by the budget, but may give rise to QFAs if costs are not fully covered.

${ }^{17}$ In 2005, explicit subsidies reached 3.7 percent of GDP for Pertamina and 0.5 percent of GDP for PLN. Fuel subsidies were higher than the entire central government's health and education budget, despite the substantial increase in domestic fuel prices in October 2005 (which brought fuel prices for industry to market price level and doubled the average price for gasoline, diesel and kerosene for households).
} 
of important cases, subsidies do not cover the full costs of operations and investment required to meet the social target. The underfunding constitutes a QFA, the cost of which is borne by the enterprise ${ }^{18}$ - leading to inefficiencies and significant fiscal risks.

A consequence of the lack of definition of the cost of PSOs in the energy sector is that it has led to cascading interenterprise arrears. There are regular reconciliation sessions between Pertamina and the government on taxes, profit transfers and subsidies owed. ${ }^{19}$ In turn, uncertainties on PSOs of large users of fuel, such as PLN and Garuda, led to mounting debt of these companies to Pertamina. These issues have been an important contributor to Pertamina's financial difficulties. The authorities have recognized the general problems of PSO management and are developing a standard approach for treating these obligations. A directorate of the MSOE was created in 2006 to report on PSOs, inventory all existing ones, and establish guidance on how they are determined, identified, contracted, and costed.

\section{Indonesia's regulatory framework for Public-Private Partnerships (PPPs) is being strengthened. \\ 1.1 .5}

Regulatory reforms have been passed in the water sector, toll roads, and land acquisition. Sector regulations are under preparation in the areas of transport (i.e., airports, ports, rail) and electricity. The Committee on Policy for the Acceleration of Infrastructure Development has been strengthened through Presidential Decree 42/2005, which together with Decree 7/1998, governs private participation in infrastructure. Presidential Decree 67/2005 sets up the basic principles on which to structure projects, to provide adequate returns to investors, and to consider users' payment capacity. It also introduces simplified procurement rules that would improve transparency in the bidding process. Decree 67/2005 also calls for the establishment of a risk management framework for PPPs to ensure an adequate monitoring of risks from these activities (few PPPs have been developed so far). Capacity to implement these regulations and monitor risks will need to be developed.

\section{Regulatory costs and the implementation of deregulation policies need further clarification. $\quad 1.1 .5$}

The government recognizes the need to improve the business environment by reducing the amount of regulations and the numerous permits that are needed for investment. The 2006 business survey noted the high cost of starting a company and the need to obtain approval from many government institutions for doing business. The coordinating ministry of the economy has been working with business organizations (such as the Chamber of Commerce) to develop measures to reduce the cost of business. Public access to regulations is available through a non-official government website http://hukumonline.com/. However, the authorities have not established clear rules for discussing new regulations or assessing the impact of these, nor have they designated the institutions to coordinate regulatory reforms.

\footnotetext{
${ }^{18}$ For example, subsidy payments only partially compensated Pertamina for the cost of its fuel (which included a fixed additional fee per barrel). This is being solved in 2006 with the introduction of a new PSO that defines retail fuel prices as Singapore MOPS (Mean of Platts) prices plus 15 percent margin and VAT and regional taxes.

${ }^{19}$ Prior to 2005, the government owed more subsidies than taxes owed by Pertamina. In 2005, it is estimated that Pertamina owes the government about Rp 17 trillion (about 0.6 percent of GDP) by end-2005, while all fuel subsidies owed by central government to Pertamina were paid.
} 
Government fiscal policies and the oil and gas sector

\section{The separation of Pertamina's role as regulator and operator has improved transparency in the oil and gas sector, particularly in the supervision of operations. \\ 1.1.4/1.1.5}

Law 22/2001 provides the legislative framework for the oil and gas sector, ${ }^{20}$ and led to the establishment of Pertamina as a limited liability company in 2003. Under the new framework, Pertamina's former upstream regulatory function was transferred to an implementation agency, BPMIGAS, whose role includes signing Production Sharing Contracts (PSCs), ${ }^{21}$ supervising and controlling PSCs, approving contractors' budgets and spending, and appointing the seller for the state's share of crude oil. Pertamina's downstream regulatory role was transferred to BPHMIGAS, which is responsible for supervising the implementation of the supply of fuel oil and for ensuring its distribution as stipulated by the government. While these agencies are in principle independent, ${ }^{22}$ they must closely liaise with the Ministry of Energy and Mineral Resources'(MOEMR's) Directorate General (DG) of oil and gas and DG of electricity and energy utilization. ${ }^{23}$

11. The fiscal regime for the oil and gas sector is in transition.

The taxation of the oil and gas sector is not comprehensively codified, since most revenues from upstream gas and oil production are based on individual PSCs signed under Law 8/1971. ${ }^{24}$ Under this law, no distinction was drawn between tax and nontax revenue. Under the oil and gas Law 22/2001, however, the provisions of the tax law in force when the PSC is signed determines company tax liability. The individual PSC arrangements are relatively simple and non-progressive (i.e., the government's share does not increase as the oil price or contractor's rate of return increases). ${ }^{25}$

\footnotetext{
${ }^{20}$ The oil and gas sector remains a significant part of the economy (about 10 percent of GDP) despite falling oil production. The government relies heavily on oil and gas revenues (29 percent of total revenues in 2006).

21 The PSC specifies the portion of total production that can be retained by the contractor to recover costs ("cost oil"). The remaining oil (including any surplus of "cost oil" over the amount needed for cost recovery) is termed "profit oil" and is divided between the government and the contractor according to a formula set in the PSC.

${ }^{22}$ They are not administratively dependent on the ministry of energy and heads of both agencies are directly appointed by the president.

${ }^{23}$ For example, DG oil and gas selects contract areas, and negotiates PSCs, including production sharing terms with the contractor and the division of production between local and central governments. DG electricity and energy prepares policy on electricity and energy formulation, and is also involved in the setting of fuel prices and electricity tariffs.

${ }^{24}$ In effect, three categories of PSC have been created - those signed before Law 22/2001 came into effect (where refund delays have been prevalent), those signed in 2002/03 (the first PSCs post 2001 law, under which BPMIGAS is expected to authorize tax refunds within 120 days), and PSCs signed in 2004 (where the contractor is only required to pay import duties and taxes).

${ }^{25}$ The after-tax split is generally weighted 85/15 towards the government in oil contracts and 70/30 in gas contracts. For older contracts, however, the oil split can be as much as 90/10 when the contractor's obligation to sell some oil at a discount for the domestic market is included. Newer contracts are more generous to the contractor because international prices are applied to domestic market obligations for oil.
} 
12. More effective implementation of the oil and gas fiscal regime is needed. $1.1 .5 / 1.2 .2$ Provisions regarding taxation included in Law 22/2001 conflict with some of the terms agreed in individual PSCs, leading to uncertainty as to how the law must be applied to different contracts, despite the existence of fiscal stability clauses. ${ }^{26}$ In particular, the procedure for VAT reimbursement needs more clarity. The VAT is directly paid to DG Tax of the MOF, which is responsible for VAT administration. Reimbursements under PSCs, however, are payable by the MOF's Oil and Gas Directorate after verification by BPMIGAS and there have been considerable payment delays. ${ }^{27}$ Also, the increased taxation authority given to regional governments requires careful coordination, to avoid conflicts between local and central government regulations or PSCs.

\section{Transparency with regard to Pertamina operations is unclear, both in terms of the policy environment and financial disclosure, although financial accounts are now being audited.

The lack of clear definition of domestic market obligation costs ${ }^{28}$ combined with the QFA described in paragraph 7, have put Pertamina in a difficult financial position. There are also weaknesses in financial reporting. Now that Pertamina is a limited liability company, it will have to comply with company Law 1/1995. To meet these requirements, the 2004 and 2005 financial statements of Pertamina are being audited by Ernst and Young. ${ }^{29}$ Pertamina's intention to schedule a corporate bond issue will also help in improving the transparency of its operations as it would have to disclose its operations and be assessed by a rating agency.

Government relations with the central bank and public financial sector

\section{Bank Indonesia (BI) is operationally independent and does not have a fiscal role, except in a crisis. \\ 1.1.4}

The BI Law 23/1999, and subsequent amendments $(2002,2004)$, confers on BI its status as an independent public entity, free from interference by the government or any other party, except for matters prescribed in the law. BI's stated policy objective remains price stability, as defined by the new inflation targeting framework. The law prohibits BI from providing credit to the government, including from buying government securities on the primary market for its own account. Exceptions to the latter rule are allowed: (i) if short-term government securities are needed for monetary control operations; and (ii) for the provision

\footnotetext{
${ }^{26}$ Fiscal stability clauses specify the duration of taxation arrangements in PSCs, which may supersede tax laws. Law 22/2001 also gives assurance for previous contracts that they remain valid until the end of the contract term.

${ }^{27}$ The authorities indicate that there were no important payment delays in 2006, whereas the industry estimated that a substantial amount still had to be paid. DG Tax audits contractors only to ensure correct VAT payments have been made. Profit shares are subject to cost audit by BPMIGAS without involvement of DG Tax. Contractor spending is audited by joint venture partners, BPMIGAS, and BPKP.

${ }^{28}$ Law 22/2001 specified that Pertamina was to retain its downstream domestic market obligation to supply local fuel for a period of four years (to November 21, 2005-though they still remain in place).

${ }^{29}$ Companies must publish their annual financial statements (including public accountants' opinion) no later than the end of the third month after the date of the financial statement. Up until now, Pertamina has not respected this requirement.
} 
of emergency financing. ${ }^{30}$ The law provides that surpluses from BI operations be transferred to the government as long as its capital is at least $\mathrm{Rp} 2$ trillion and after: (i) allocating 30 percent for special reserves; and (ii) reinvesting the surplus into general reserves so that capital and general reserves are at least 10 percent of all monetary liabilities. No profit transfer has occurred in recent years. Treasury balances at BI are not remunerated, ${ }^{31}$ an issue under discussion in the context of implementing a single treasury single account and maximizing returns on idle balances. Reforms currently being undertaken in cash management will help introduce more market-based relations between BI and MOF.

\section{State-owned banks, which represent about 47 percent of the total portfolio of the banking system, have reduced the extent of their QFAs.

After starting as government entities for channeling subsidized credits - provided principally through rediscounting facilities from BI to specific sectors of the economy-state-owned banks have evolved into full-fledged commercial banks. QFAs during the 1980s and 1990s led to the need to recapitalize these banks. The extent of such QFAs have now diminished, as reflected by the state-owned banks' NPLs being reduced to about 6 percent of total loans. ${ }^{32}$ State-owned banks are under no legal or regulatory obligation to provide credit to government or public enterprises. Their financial performance is monitored by the MSOE and subject to prudential regulation and supervision by BI. Regional development banks, owned by provincial governments, are reputed to have significant non-performing loans.

\section{$\underline{\text { Fiscal management relations among the branches of government }}{ }^{33}$}

\section{The fiscal roles of the executive and legislative branches are defined in law and evolving in practice.

Fiscal relationships between the government and legislature are defined in the State Finances Law 17/2003. The House of Representatives (DPR) is the principal legislative body and it plays a significant role in shaping the budget and fiscal policy. ${ }^{34}$ The budget is passed in

\footnotetext{
${ }^{30}$ If a bank experiences financial difficulties that have a systemic impact, BI may provide an emergency financing facility funded by the government. BI still has on its balance sheet a redeemable note, which replaced the BI liquidity support bonds provided during the crisis.

${ }^{31}$ Although Treasury Law 1/2004 envisages remuneration of government deposits, as a transitional measure, Article 71 states that the remuneration should be at the same rate of interest as that paid on non-marketable government bond notes held by BI (most of these bear a rate of 0.1 percent per annum).

${ }^{32}$ However, this share is higher than the average for the entire banking sector. State-owned banks hold 70 percent of the banking system's nonperforming loans. A large increase in banks' NPLs was observed in 2005 as tighter regulations on NPLs classification were introduced and new problem loans emerged (including new NPLs as well as previously misclassified loans), particularly at Bank Mandiri and BNI.

33 This section draws on the Country Governance Assessment Report: Republic of Indonesia, ADB, 2004.

${ }^{34}$ The DPR and the Regional Representative Council (DPD) form the People's Consultative Assembly (MPR), which deals with constitutional amendments and consideration of the accountability reports of constitutional bodies, such as the president, DPR, DPD, BPK and the supreme court. The DPD was created through a constitutional amendment in 2001, but only began operations in October 2004 after the first election of its council members. It advises the DPR on intergovernmental relations and can give its views on the macro-fiscal framework, but has no powers over legislation or the budget.
} 
agreement between the president and the DPR. The process (discussed in detail in Section I.B) involves an examination by DPR of both the macroeconomic framework and macrofiscal policies (through DPR's Budget Committee) and the detailed budget allocations (through 11 sectoral commissions). The relative roles of the executive and legislative branches in this area are evolving. For example, the DPR has been heavily involved in the debate and modification of technical assumptions and detailed expenditure items, which are both usually seen as being within the province of the executive.

17. The legal-based system adds complexity to fiscal policy-making.

Policy-making in Indonesia relies more heavily than most countries on promulgation of law and implementation through a hierarchy of decrees and regulations. These are intended to establish explicit legal support for all government policies. The ranking is along the following lines: laws, government regulations, presidential decrees, regional regulations, and ministerial decrees. ${ }^{35}$ The system, combined with the widely recognized low level of compliance with regulations, places a premium on careful drafting and consultation regarding new legislation. In a number of instances, conflicts between laws initiated by different agencies of government have contributed to delays in formulating or implementing policy. These factors can slow the momentum of reform. Mechanisms of coordination through three coordinating ministries and bilateral administrative efforts focus more on individual rather than systemic issues.

\section{$\underline{\text { Fiscal management relations among different levels of government }}$}

\section{Transfers and revenue sharing between central and regional governments are well defined, but levels are subject to oil price fluctuations; and further clarification of expenditure responsibilities is required.

Considerable decentralization to the 33 provinces, and especially, the 434 districts, took place from 2001 onwards. The two legal pillars of regional autonomy are: (i) Law 32/2004 on Regional Governance, which focuses on administrative and political decentralization and includes the guiding references to the devolution of expenditure responsibilities; and (ii) Law 33/2004 on Fiscal Balance ${ }^{36}$ governing the distribution of resources across regions. Subnational governments' budget revenues depend mostly on government transfers through revenue sharing arrangements, block grants or specific allocation grants - as well as specific grants for autonomous regions and adjustment. These arrangements are clearly defined (see Box 2), but fluctuations in international oil prices give a degree of uncertainty to the level of transfers and revenue shares going to the regions. ${ }^{37}$ With the laws drafted by different

\footnotetext{
${ }^{35}$ Since 2004, the use of Presidential and Ministerial Decrees has been mainly replaced by Presidential and Ministerial Regulations.

${ }^{36}$ Laws 32/2004 and 33/2004 made substantial revisions to the two original decentralization laws adopted in 1999. In an effort to improve coordination, MOF and MOHA jointly developed regulation 58/2005 to reconcile differences between Laws 32 and 33 of 2004.

${ }^{37}$ For example, the high oil price used for the 2006 budget is expected to increase subnational revenues by about 47 percent and represents a significant administrative challenge given the surpluses that will result, the lack of absorption capacity, and overlapping expenditure responsibilities of central and subnational governments.
} 
ministries (ministry of home affairs-MOHA and MOF), a clear definition of the roles and functions of different levels of government has not yet been established, and coordination between central and regional governments (e.g., conflicting sectoral laws, ${ }^{38}$ authority over civil service and rules on financial management) has been weak. ${ }^{39}$ Regulations that clearly delineate expenditure responsibilities have not been issued. ${ }^{40}$

\section{The decentralization laws allow regions to borrow, but under MOF supervision. ${ }^{41}$}

Under Law 33/2004, the minister of finance establishes the cumulative limit on regional government loans in August of each year. Regional governments are allowed to borrow externally, although they must seek central government approval before any loan contract is signed. The law limits domestic borrowing: the total stock of debt must not exceed 70 percent of a region's revenue and projected debt service to revenue ratio must be limited to 40 percent. The law also states that borrowing can only be done for projects that generate a financial return. The central government can withhold the general grant (DAU) if a province fails to meet its debt obligations. However, borrowing limits do not apply to all sources of debt, such as local government guarantees or local enterprise borrowing. The central government has not yet established an appropriate reporting system for local government debt and guarantee provisions.

\footnotetext{
${ }^{38}$ For example, while the decentralization law devolves some authority over fisheries to subnational units, sectoral legislation posits that all public service functions related to fisheries are located at the center.

${ }^{39}$ Fiscal management capacity varies greatly in provinces and districts. Some have made considerable advances in applying the principles of the state finance law. Jogjakarta is an example of a province that is relatively advanced in improving fiscal transparency. It has adopted a comprehensive approach and is simultaneously undertaking reforms in organizational arrangements, and financial and human resource management. Results so far include: the introduction of a rolling 3-year plan for budget preparation, the participation of civil society in local parliamentary budget discussions, publication of financial statements that include balance sheets (e.g., in Sleman district - see www.sleman.go.id), a significant reduction in provincial administration staff, and the provision of relatively comprehensive provincial information to the public (see http://www.pemda-diy.go.id). Other provinces and districts have yet to develop such practices.

${ }^{40}$ Regulations on subnational borrowing, fiscal balance (tax sharing), grants, regional financial information system and public financial management were issued in 2005. A revised regulation on expenditure assignment is expected to be issued in 2006 although it is unlikely to solve the current weaknesses as: (i) it leaves many details on service assignment to future ministerial decrees; (ii) and does not distinguish between obligatory and non-obligatory functions.

${ }^{41}$ A temporary ban on long-term subnational borrowing, which was introduced every year by ministerial decree, was lifted at end-2004. This ban, and the non-possibility for borrowing prior to 2001, made Indonesian subnational governments default free.
} 


\section{Box 2. Revenue Sharing and Central Government Transfers to Local Governments}

Revenue sharing, a general grant, and a special allocation grant represent the main source of revenues for subnational governments. In addition, there are grants for specific autonomous regions and for adjustment. In the 2006 budget, these represented respectively 27, 66, 5 and 2 percent of total resources transferred to subnational governments.

Revenue sharing. Revenues collected by the central government on account of property tax, personal income tax and natural resources (e.g., oil, gas, forestry, and mining) are shared with subnational governments according to specified rates. These vary from 15 percent on total collection for oil to 30 percent for gas revenues and 80 percent for general mining, forestry (except for Dana Reboisasi, where the rate is 40 percent), and fishing. Special rates apply to Aceh and Papua, where sharing rates range between 55 and 70 percent for oil.

The DAU or general grant. Law 33/2004 requires that the central government transfers to subnational governments a minimum of 25.5 percent of central government revenues after tax sharing, to be increased to 26 percent by 2008 . Districts receive 90 percent of the DAU pool, with the provinces receiving the other 10 percent. The DAU allocation to individual provinces and local districts is determined by a formula that takes into account the difference between a region's fiscal needs (which depends on indicators such as population, human development index, land area and the construction price index) and fiscal capacity (defined as the sum of own revenues and shared revenues). The DAU distribution also includes a "basic amount" that must cover at a minimum the civil service wage bill and a "contingency allocation."

DAK, or the special allocation grant, was established for earmarked transfers. The law states that DAK can be used for special needs of the regions, including emergencies, and for financing central priorities at the regional level. It consists of seven types of programs: education, health, rural roads and irrigation, public administration infrastructure, sea and fishery, agriculture and environment. Regions apply to the central government for the grant with proposals that meet the allocation criteria.

Grants for specific autonomy regions and for adjustment. Based on Law 21/2001, the Papua province is allocated a grant equal to 2 percent of the total general grant for 20 years. This grant is directed to enhancing education and health services in the province. Grants for adjustment are allocated to provinces that receive general grants that are less than the previous year, or for certain regions that qualify for additional funds for roads and other physical infrastructure.

The legal and administrative framework for budget management

\section{The laws governing budget management clearly specify the responsibilities of the minister of finance and comprehensive regulations are being developed. 1.2 .1}

The 1945 Constitution establishes basic budget-related provisions, including requiring that the annual state budget and all taxes be laid down in law (Article 23). For budget management, the constitution is supplemented mainly by the State Finances Law 17/2003 and the Treasury Law 1/2004, both of which are accompanied by government regulations. While the president, as head of government, has overall authority to exercise national fiscal management, Law 17/2003 clearly delegates the responsibility of overall fiscal management of central government finances to the minister of finance as chief financial officer. The law also assigns responsibilities to individual ministers, governors and other local authorities for 
financial management in their jurisdictions. The responsibilities of the minister of finance for central government treasury management, including for revenues, expenditures, assets, liabilities, cash, internal control, and government banking arrangements, are clearly elaborated in Law 1/2004, which also includes similar legal provisions for treasury managers at subnational levels. The public finance law was adopted with the view to supporting the eventual implementation of a performance-based budget system. According to the system, individual budget managers (chief operating officers) are responsible for preparing financial reports on the execution of their budget and the achievement of output at the spending unit level. The minister of finance consolidates those reports for the president, who submits this consolidated financial report to the DPR, as required by the constitution.

21. Provisions of the new laws have not been fully implemented.

Not all of the regulations related to Laws 17/2003 and 1/2004 had been issued as of April 2006 - and some of the laws' provisions have not been fully implemented. The laws' transitional arrangements allow a few years for full implementation for some aspects. For example, it is intended to implement those relating to accrual-based income and expenses by 2008. There are other transitional difficulties. For instance, the state finances law states that all ministers are responsible for paying all nontax revenues into the State treasury. In certain cases, however, ministries still maintain commercial bank accounts outside the control of the Treasury.

The legal and administrative framework for tax policy and administration

\section{The legislative basis for taxation (other than oil and gas) is clear, but delays in implementation leave scope for discretion.

The rules and procedures governing central government tax administration are set out in two different laws: one on tax administration and the other on arrears collection..$^{42}$ Direct and indirect taxes are governed by an income tax law, a law on value added tax and sales tax on luxury goods, and a land and building tax law. Some of these laws (e.g., the VAT law) are complex and are not well implemented. ${ }^{43}$ Customs duties and other import levies are governed by the customs law. These laws often leave key details to implementing regulations, which are not always issued (such as the one on tax incentives). This leaves considerable discretion to tax or customs officials in their dealings with taxpayers. ${ }^{44} \mathrm{~A}$ tax package ${ }^{45}$ under discussion at parliament has created additional uncertainty about the income

${ }^{42}$ Law 6/1983 on general provisions and procedures for taxation (as amended by Law 16/2000; also referred as KUP law) and Law 19/2000 on enforced collection of tax arrears.

${ }^{43}$ For example, the VAT law was criticized in the past by the business community because of long delays for VAT refunds. These delays have been considerably reduced in the past two years, except for the oil and gas industry.

${ }^{44}$ For example, the customs law provides for a wide range of fines as penalties but leaves specifics to regulations.

45 The tax package proposes revisions to the income tax law, VAT and luxury sales tax law, and the laws governing general administration procedures. Some of its provisions, notably on tax administration, continue to generate a considerable debate with the business community. The amendment draft of the Customs Law 10/1995 and the Tariff Law 11/1995 are also being discussed in parliament. 
taxes that will have to be paid and new tax administration procedures. In addition, repeated announcements of a possible tax amnesty by different government ministers may have hurt tax compliance and clouds the taxation environment even though it is not included in the draft tax package.

\section{DG Tax's organizational structure is being modernized to address potential inefficiencies.

Model tax offices - featuring new organizational arrangements, improved taxpayer services, and a governance framework - are being set up for administering large, medium, and small taxpayers. DG Tax (which does not cover customs nor oil and gas taxation) is currently in a transition period where its model tax offices ${ }^{46}$ are organized functionally (assessment, collection, audit, enforcement, and appeal) and by taxpayer size, while its organization at headquarters is still based on types of taxes (such as a VAT section or a corporate income tax section). The latter structure diverges from good international practice, where tax administrations are organized according to tax administration functions or types of taxpayers. ${ }^{47}$

24. Tax exemptions are extensive and tax expenditures are not fully reported. $\quad 1.2 .2$ A large number of exemptions are included in the VAT Law and government regulations. These include exemptions in electricity (only households with meter capacity above 6,600 watts are taxed), public telephones, and self-constructed assets. Such exemptions result in these items being favored over other discretionary purchases. Additional tax exemptions and tax incentives are envisaged as part of the tax package currently being debated in the DPR. A list of all tax exemptions, old and new, and potential costs are not publicly available. Tax expenditures have been included in revised budgets since $2003 .{ }^{48}$ However, these have been mainly limited to income tax deductions and VAT exemptions granted to state-owned companies. $^{49}$

\section{The powers of the tax administration are clearly defined in the laws but lack standard enforcement rules.

The tax administration laws provide the DG Tax with broad authority to access information from a taxpayer and a third party in conducting an audit. However, standard powers are lacking such as: (i) an administrative summons power for civil audit; (ii) DG Tax's authority to access a specific taxpayer's banking information in the course of a bona fide audit; (iii) insufficient authority to assess taxes when taxpayers fail to file a tax return or keep sufficient books of account to allow for a proper audit of a tax liability; and (iv) limited ability to seize tax debtors' bank deposits. The lack of these enforcement powers, which are

\footnotetext{
${ }^{46}$ DG Tax uses a single taxpayer identification number (TIN) for income tax and VAT. A different TIN is used for customs and excise taxes. Plans are being made to create one single identity number per taxpayer.

${ }^{47}$ Recent taxpayer survey showed an 85 percent satisfaction level.

48 These are recorded as additional revenues and expenditures (tax subsidy). The information is not included in the original budget, as higher revenues would lead to additional transfers to provinces.

${ }^{49}$ These include penalties foregone for PLN, PT Indonesia power, VAT for Pertamina in 2003 and 2004, and imports of spare parts by Garuda.
} 
common to modern tax administration, raises the risk that the DG Tax may resort to nonstandard measures such as speculative assessments or detention of taxpayers ${ }^{50}$ for ensuring compliance.

\section{Taxpayers' legal rights are clearly defined, but the existing dispute resolution system heavily favors DG Tax.}

A charter of taxpayers' rights has been established to set out legal obligations and rights of taxpayers ${ }^{51}$ and a complaints center has been established at DG Tax headquarters to report tax officials' misconduct. ${ }^{52}$ However, the dispute resolution system remains biased in favor of the DG Tax as: (i) disputed tax assessments and associated penalties remain payable, and therefore subject to collection while under objection or appeal; (ii) objections are generally heard by the DG Tax office that first issued the assessment; and (iii) no separate appeals unit exists within the DG Tax office to adjudicate an objection. ${ }^{53}$ The existing code of conduct that sets norms for acceptable behavior among DG Tax staff does not include explicit sanctions and penalties for violations and has only been introduced at a relatively small number of pilot offices. ${ }^{54}$ Proposed amendments to the tax package submitted to the DPR in September 2005 do include provisions that would remedy some of these weaknesses. ${ }^{55}$

\section{Clarity of internal control of revenue administration}

\section{Audit procedures for taxpayers and the tax administration's internal monitoring mechanisms need further improvement. 3.3 .3}

The DG Tax has recently developed a computerized system that uses a risk-based selection method to select tax returns for audit. Contrary to good international practice, most refund claims are audited prior to payment regardless of the taxpayer's compliance history (except for gold claims taxpayers). DG Tax does not conduct tax audits of the oil and gas industry, except for VAT. No internal audit system exists in the tax administration to ensure financial accountability of tax collection, staff and systems. DG Tax can be audited by the external audit office (BPK) and the MOF's Inspector General (IG), whose special investigative unit is being reinforced to investigate both tax and customs officials' misconduct. No specific legal

\footnotetext{
${ }^{50}$ Law 19/2000 concerning Tax Collection with Coerce Warrants provides some safeguards to prevent arbitrariness.

${ }^{51}$ Article 26 of the KUP law states that a taxpayer can appeal a tax assessment to the tax court after a decision on the case has been issued by the DG Tax. However, DG Tax is allowed 12 months to reach such a decision.

52 The proposed headquarters organizational structure would include a separate tax appeals unit.

${ }^{53}$ Currently, cases are handled by one of the operational sections: either the VAT section for VAT assessments or the income tax section for income tax assessments.

${ }^{54}$ While the need to apply sanctions to tax officials that do not adhere to the code is explicitly stated, specific sanctions are still left to future regulations (and are not in the tax law or proposed amendments).

${ }^{55}$ Recent proposals include (i) the introduction of an indirect assessment method; and (ii) the modification of the procedures on the objection process, which allows the taxpayer to initially only pay the tax amount it does not contest.
} 
provision gives assurance that the tax administrators are free from political interference in interpreting the tax laws.

$\underline{\text { Public servants' code of behavior and anti-corruption activity }}$

\section{There are several specific codes of ethics; asset declarations are required from high officials.

There is no single code of ethics covering the entire civil service. However, codes of ethics have been established in specific agencies. Both the Financial and Development Supervisory Agency (BPKP) and BPK, for instance, have established such codes. Law 28/1999 ${ }^{56}$ was adopted to uphold the law against criminal acts by high-level officials and functionaries having strategic functions (including ministers, governors, judges, and ministry echelon I (DG-level) staff). These officials are required to report and announce their assets before and after holding their positions. The Anti-Corruption Commission (KPK), discussed below, has a mandate that includes examination of the wealth reports of government officials. ${ }^{57}$

\section{The Anti-Corruption Commission has become operational.}

The KPK (http://www.kpk.go.id) was established by law in 2002 as a State agency that performs its duties and authority independently, free from any and all influence. ${ }^{58}$ It coordinates with other entities combating corruption, conducts investigations and prosecutions against corrupt acts, performs preventative actions against corruption, and monitors state governance. It has initiated and signed memoranda of understanding with some provincial and local governments to establish and support good governance at the subnational level. More than 9600 public complaints (not all relating to corruption) have been received by KPK, indicating a high level of expectation from the public. Annual reports summarize KPK's activities, which are published within three months after the end of each year. Although its capacity to carry out prosecutions is limited to a few cases per year, its focus is on high-level large-scale corruption. To prevent abuse of KPK's extraordinary powers, KPK has adopted two codes of ethics — one for its commissioners and another for its staff.

\footnotetext{
${ }^{56}$ Titled: On The State Organizer Who Is Clean And Free From Corruption, Collusion And Nepotism.

${ }^{57}$ The IGs should also ensure observation of ethics codes, but cite lack of resources as a factor impeding their effectiveness in this area.

${ }^{58}$ See Law 30/2002 establishing the Commission for the Eradication of Criminal Acts of Corruption.
} 


\section{B. Open Budget Preparation, Execution, and Reporting}

The budget preparation process: clarity and consistency of process and presentation

30. The annual budget process is clearly defined in law and regulations.

The State Finances Law 17/2003 and its accompanying regulations clearly outline the steps of the budget formulation and adoption processes (Box 3). Budget preparation begins 11 months before the new year begins and the DPR is involved twice: first, to agree on budget policies, priorities and expenditure ceilings (6-7 months before the new fiscal year); and second, to examine the draft budget and approve it two months before the beginning of the new fiscal year. At both stages, a detailed draft budget is provided to parliament. No explicit limits are imposed on parliament's power to amend the draft budget. As discussed below under budget execution, prior to implementation, the budget approved by the DPR is developed in greater detail down, to individual spending units' work plans.

\section{The budget classification is not yet fully consistent with contemporary international standards.

The budget classification structure is based on organizational, functional, program/activity, and economic classifications. The functional classification of expenditure is broadly consistent with international standards. ${ }^{59}$ However, the detailed economic classification needs further development to attain full conformity with GFSM2001 standards. This classification contains a relatively large amount (around 6 percent of total expenditures) for unallocated expenditures, which reduces transparency. Finally, although the program classification is used, budgetary programs that link output to performance have yet to be developed.

\section{The relative authority of the legislature and executive over different levels within the new classification have not yet been fully defined.

The State Finances Law 17/2003 mandates that the budget approved by the DPR "shall give details of organizational units, functions, programs, activities, and types of expenditure" (Article 15 (5)). One consequence of prescribing appropriations at activity level (i.e., one level below program) is that the parliament must approve the budget at the level of budget user (satker) rather than at the higher ministry level, as commonly found in other countries. Approval at this level of detail makes the budget somewhat inflexible during implementation. ${ }^{60}$ To partially overcome this lack of flexibility, the 2006 budget law provided authority to the MOF to re-appropriate between satkers of the same ministry, and between activities under the same program (with some restrictions in each case).

\footnotetext{
${ }^{59}$ See "Indonesia: Report on the Observance of Standards and Codes-Data Module," IMF Country Report No. 05/255, July 2005, http://www.imf.org/external/pubs/ft/scr/2005/cr05255.pdf.

${ }^{60}$ There were about 19,500 budget users (satker) covered by the 2006 budget appropriations.
} 


\begin{tabular}{|c|c|}
\hline \multicolumn{2}{|r|}{ Box 3. The Central Government Budget Preparation Process } \\
\hline Month 1/ & Description of Stage \\
\hline \multicolumn{2}{|c|}{$\begin{array}{l}\text { The fiscal year is January 1-December 31, in which all authorized cash expenditures must be made. There is no complementary } \\
\text { period. }\end{array}$} \\
\hline February-March & $\begin{array}{l}\text { MOF and BAPPENAS issue a joint budget circular to line ministries. The circular provides } \\
\text { guidelines on the preparation of ministries' work plans (WPs) and includes indicative budget } \\
\text { ceilings for each ministry, broken down by programs. }\end{array}$ \\
\hline March & $\begin{array}{l}\text { Ministries prepare their initial WPs, in line with the government work plans and their own } \\
\text { strategic plans. }\end{array}$ \\
\hline April-May 15 & BAPPENAS, in coordination with MOF, reviews WPs. \\
\hline Mid-May (Art.13) & $\begin{array}{l}\text { Government submits to DPR the Fiscal Policy and Budget Priorities document, which includes } \\
\text { description of the macroeconomic framework, fiscal policies for the budget year, the government's } \\
\text { WP and ministerial WPs. }\end{array}$ \\
\hline May 15-June 15 & $\begin{array}{l}\text { Discussions are held by MOF and parliamentary commissions on fiscal policy, ministries' WPs } \\
\text { and proposed expenditures, including transfers to local governments. }\end{array}$ \\
\hline June 15 & $\begin{array}{l}\text { MOF issues a revised budget circular including a preliminary budget ceiling for ministries' } \\
\text { programs, taking into account the agreement reached with the DPR on budget policies and } \\
\text { priorities. }\end{array}$ \\
\hline June 15-July 15 & $\begin{array}{l}\text { Ministries, together with parliamentary sectoral commissions, discuss the WPs in line with the } \\
\text { preliminary ceilings issued by the MOF. WPs are detailed by administrative units, programs, } \\
\text { activities, and broads economic categories of expenditures. Ministries submit discussed WPs and } \\
\text { budgets to the MOF and BAPPENAS for review. }\end{array}$ \\
\hline July 15-Aug 15 & $\begin{array}{l}\text { MOF and BAPPENAS review consistency of ministerial WPs and draft budgets with preliminary } \\
\text { ceilings. MOF compiles the reviewed ministerial WPs, the draft State Budget and Financial Note, } \\
\text { which defines budget priorities for the next budget year and which is discussed in Cabinet. }\end{array}$ \\
\hline $\begin{array}{l}\text { August } \\
\text { Art. } 15 \text { (1) }\end{array}$ & $\begin{array}{l}\text { Government submits the draft State Budget and Financial Note including the reviewed ministerial } \\
\text { WPs to the DPR. President delivers the annual budget speech. }\end{array}$ \\
\hline August $15-$ October 31 & $\begin{array}{l}\text { Sectoral Committees and the Budget Commission of the DPR review the macro-assumptions, } \\
\text { revenues, expenditures and financing of the draft budget. }\end{array}$ \\
\hline October 31 & DPR in plenary session approves the annual budget as a State Budget Law (APBN). \\
\hline Art. 15 (4) & $\begin{array}{l}\text { Appropriations are detailed by ministerial head agencies, functions, sub-functions, programs, and } \\
\text { the economic classification. }\end{array}$ \\
\hline November & $\begin{array}{l}\text { MOF, in coordination with parliamentary sectoral commissions, breaks down the APBN into } \\
\text { organizational units, functions/sub-functions, location, and types of expenditure. }\end{array}$ \\
\hline December $1-31$ & $\begin{array}{l}\text { Ministries prepare their documents on budget implementation (allotment requests or draft DIPAs) } \\
\text { and submit them to MOF by December } 15 \text {. Ratification by end-December by MOF of the } \\
\text { ministerial documents on budget implementation (DIPAs). }\end{array}$ \\
\hline
\end{tabular}

Medium-term planning and fiscal sustainability

\section{National development plans give broad priorities, but are being used alongside annual and medium-term budget plans.

National planning is a well-ingrained practice, centered round the preparation of national development plans. ${ }^{61}$ Following a review of the planning function, the National Development Planning Law 25/2004 took account of the greater authority given to regional and district governments under the 1999 decentralization laws. Law 25/2004 requires the National Development Planning Agency (BAPPENAS) to participate actively in the drawing up of macroeconomic targets and the targets for the annual state budget, as well as to prepare 5-year national development plans and long-term (20-year) plans. The 5-year development

\footnotetext{
${ }^{61}$ The Elucidation of the State Finances Law 17/2003 states, however, that "the setting out of development targets in a five-year plan is widely considered to be an unrealistic endeavor and increasingly out of line with the needs of government."
} 
plan guides the implementation of the elected president's platform during his/her five year term. The plan is implemented through the annual government WPs. The plan's targets are adjusted periodically if actual developments deviate substantially from plan targets. However, the 5-year plan is not updated annually - its main purpose is to guide BAPPENAS qualitatively on expenditure prioritization.

\section{The MOF has been actively developing a medium-term expenditure framework} (MTEF) to guide budget policy.

At present, budget plans are prepared only on an annual basis. The preparation of a fullfledged MTEF, synchronized with the medium-term development plan, and regularly updated for changes in the macroeconomic framework and fiscal policy objectives, is planned by 2008 for all ministries. In 2006, preliminary plans for pilot MTEFs are still at an early stage and are being drawn up.

\section{Medium-term objectives for the central government deficit and gross debt have not} been included so far in the budget document.

Starting from 2007, however, the budget will show projections for the overall balance and debt of central government, although projections reported in the budget will not show medium-term revenues, expenditures and financing sources. Medium-term debt sustainability analysis is not yet conducted systematically. The proposed publication of a "Borrowing Strategy" paper by BAPPENAS in early 2006 and the creation of a new Directorate General in the MOF for managing public debt and risks will, however, facilitate systematic debt sustainability analyses in the future.

\section{The budget documents submitted to Parliament do not include an analysis of the sensitivity of the estimates to changes in economic variables and the main fiscal risks are not disclosed.

However, DG Budget, BAPPENAS and the MOF all carry out sensitivity analyses of the main fiscal variables to changes in key assumptions such as growth, the oil price and volume, and the exchange rate. Work is being initiated on data compilation and analysis of other elements of fiscal risk such as contingent liabilities and risks associated with infrastructure.

The macroeconomic framework and policy basis for the budget

\section{The overall balance of central government is the main fiscal policy}

indicator.

The budget presented to the DPR by the president also includes the primary balance, but does not show other alternative indicators of the fiscal stance such as the non-oil deficit. ${ }^{62}$ Such an approach presents only a partial view of the overall fiscal stance, given the significance of oil and gas revenues, the limited fiscal information on subnational governments, and the extensive range of off-budget and quasi-fiscal activities.

\footnotetext{
62 The overall balance, excluding oil revenues and direct oil expenditures, as a proportion of non-oil GDP, removes the effects of variability due to oil price fluctuations and allows a clearer focus on the impact of fiscal stance of the non-oil sector. For further discussion, see IMF Guide on Resource Revenue Transparency, paragraphs 106-109.
} 


\section{The overall balance of general government is not well monitored because regional fiscal reporting is weak.

The consolidated expenditures of all subnational governments accounted for about 30 percent of total general government expenditure in 2004/2005 (see Box 1). Despite their importance for general government fiscal transactions, the requirements set by law, and efforts by the national authorities, subnational governments do not provide their approved budgets and budget execution reports to the central government in a timely manner. Limited capacity, particularly in the more remote regions, is an important factor, but there were also weaknesses in coordination between the MOF and MOHA in establishing consistent standards for reporting. At the beginning of 2006, the central government had only received 90 percent of subnational governments' budget outturns concerning fiscal year 2004, a lag of more than 12 months.

\section{Quantitative fiscal rules have been established, but they cannot easily be monitored.}

The State Finance Law and Government Regulation 23/2003 prescribes that the consolidated national and local government budget deficits be limited to 3 percent of GDP in any given year, and that total central and local government debt not exceed 60 percent of GDP. The regulation requires the minister of finance to monitor the growth of local government deficits and borrowings, and to establish mechanisms to ensure that the fiscal rules are respected. These fiscal rules are rendered ineffective by the lack of timely reporting of subnational fiscal data to the MOF. Debt ceilings for different levels of governments, including province/districts, have not yet been established, neither have effective enforcement mechanisms been implemented.

\section{Budget forecasts and underlying macroeconomic assumptions are clearly presented} in the annual budget.

The main macroeconomic assumptions, including real economic growth, inflation, interest rates, oil prices and volumes, are provided in the budget documents. Projections of these variables are prepared collaboratively, by a committee of technical staff from BAPPENAS, the MOF, the National Statistics Office (BPS), the BI, the MOEMR, and the Coordinating Ministry of the Economy. The committee periodically reviews macroeconomic assumptions and revises them as appropriate. The parliamentary budget committee also examines the macroeconomic framework and suggests modifications to assumptions. Spending and revenues may, as a consequence, be revised upwards by the DPR commissions and budget committee relative to the government draft budget.

\section{Estimates of new initiatives and the ongoing costs of government policies are not yet} distinguished at an aggregate level in the budget documents.

Government Regulation 21/2004 on working plans and budgets of state ministries requires forward estimates, for three years beyond the budget year, to be prepared on the basis of programs and activities already approved. Until MTEFs become fully operational across central government, it will not be possible to distinguish the aggregate costs of ongoing activities clearly from new spending proposals. In the meantime, new programs can be introduced into ministries' one-year workplans and budgets, provided they do not exceed the expenditure ceilings proposed and revised at successive stages of the budget preparation cycle. 


\section{Clarity of control of budget execution}

42. Basic internal control procedures are in place.

Spending units' DIPAs are the key documents required to authorize government spending and form the basis for expenditure control. Ministries' expenditure ceilings are set for 19,500 individual spending units throughout the country and these are broken down by sub-activities for programs and a detailed economic classification. Budget execution can begin once the detailed budget is formally approved by a presidential regulation. MOF regulations cover various aspects of budget execution, including allotment documents (DIPAs), payment claims to treasury offices (KPPNs), and transaction level accounting. ${ }^{63}$ The treasury records expenditure transactions at the payment stage. The expenditure control system does not provide for central recording of commitments. Operational control over expenditure stages such as commitment and verification of delivery of goods and services are undertaken by budget users. The Government Financial Management and Revenue Administration Project, which is now being implemented, envisages the recording of expenditure commitments. Realization of this objective will, however, require electronic networking of budget users and treasury offices.

\section{Transparency is clouded by a multitude of bank accounts, but these are being consolidated.

Thousands of government bank accounts in commercial banks are operated by the treasury and budget users. The treasury itself maintains multiple bank accounts, both in rupiah and in foreign currency, at BI. There are also an unknown number of extrabudgetary bank accounts. Regulations associated with Law 1/2004 will address this weakness and provide for: (i) the installation of treasury single account (TSA) at BI; (ii) the conversion of operational bank accounts at commercial banks into zero-balance transit accounts; and (iii) a mandatory review at MOF of bank accounts of all state agencies outside treasury oversight, with a view to close those that do not serve the public interest. Pilot runs for testing zero-balance arrangements with commercial banks have been successful. The task of identifying bank accounts outside treasury control is expected to be initiated in 2006, once the government regulations on cash management are approved. It is planned to place all government bank accounts under treasury oversight and to complete the consolidation of all government cash balances into the TSA by mid-2007.

\section{The effectiveness of cash management needs to be improved.}

The KPPNs depend only upon the DIPAs provided by the budget user at the beginning of the year for administering disbursements. The discipline of forecasting in-year cash flows at the treasury has not yet been established, but work to develop reliable forecasts of cash flows for treasury operations is now underway.

\footnotetext{
${ }^{63}$ MOF Regulation 96/PMK.06/2005 governs DIPA administration and Regulation 134/PMK.06/2005 governs KPPN payments. Government accounting standards cover transactional level recording, consolidation of accounts, and the generation of financial statements.
} 
45. The cash based accounting system generates timely records of revenue and expenditure transactions, but does not track monthly arrears.

Transaction records are electronically transmitted to the directorate of accounts at treasury headquarters for consolidation and generation of periodic reports on budget execution. The cash-based treasury system does not track payment arrears on a monthly basis; although DG Treasury's plans to move towards an accrual recording system would make it possible. Other than in relation to arrears to SOEs, payment arrears have not been identified as a general problem.

46. The internal audit framework of the government is extensive but scope and organization do not match needs.

The internal audit function is carried out at central government through two mechanisms:

(i) there are IGs in each spending ministry; and (ii) the BPKP, at the president's office, with government-wide jurisdiction. The IG represents the principal internal audit apparatus of a ministry. Taking as an example, the IG at the MOF has a span of work comprising many DGs and agencies at MOF headquarters and over 800 regional offices around the country. For this task, the IG is modestly staffed (around 500 employees including 280 auditors) and as a result, several important units of the MOF have not been audited by the IG. The scope of IG audit activities have so far been limited to compliance audit.

\section{BPKP fulfills a role closer to external audit than internal, management-oriented} audit.

BPKP, established in 1983 by a presidential decree, has been entrusted with extensive responsibilities related to central government finances including auditing the activities of spending ministries. Since the 1999 decentralization BPKP no longer has jurisdiction over regional government entities; internal audit of provincial and district finances is conducted by Bawasdas. In relation to its decreased duties, BPKP is well staffed with around 7,000 employees including 5,500 certified auditors. It also has responsibility for formulating policies for audit supervision of the government and training of IG staff. Internal audit responsibilities related to ministries are shared between BPKP and the IG, with an unclear distinction between their mandates. Audit reports of BPKP are presented to the president and those of the IG to the concerned DG, and to the minister. Both kinds of report are made available to the BPK, but not to the public.

48. Procurement rules were clarified by a new decree adopted in 2003 , but enforcement is yet to become effective.

A public procurement law has not been adopted. However, Presidential Decree 80/2003, ${ }^{64}$ provides a sound basis for open and competitive procurement practices and largely conforms with international public procurement standards. ${ }^{65}$ The decree applies to procurement at both

\footnotetext{
${ }^{64}$ Decree of Ministry of Residence and Regional Infrastructure No. 339/KPTS/2003 provides guidelines for implementing the presidential decree.

${ }^{65}$ See ADB/OECD, "Thematic review on provisions and practices to curb corruption in public procurement" available on http://wwwl.oecd.org/daf/ASIAcom/pdf/trpp indonesia.pdf.
} 
central and local government levels. A public procurement office has not been established, since public procurement is decentralized to each government department, agency, or SOE. For each procurement of goods or services, there is a certified project officer and a procurement committee. The decree envisages that project officers, suppliers, and the procurement committee are subject to a code of conduct, but progress in implementation has been slow. Moreover, the internal control framework is weak and does not foster compliance. There is also a conflict of interest in the appeals mechanism, with appeals being handled by the user or procuring agency. A World Bank report concluded that the core problem with respect to public sector procurement is weak enforcement. ${ }^{66}$

\section{A new civil service law was adopted in 1999 but the rules for applying it - at central and local government levels — are unclear; performance has limited impact on pay.

The Civil Service Law 43/1999 assumes the existence of a national civil service. In contrast, the decentralization Law 32/2004 assigns the responsibilities for the overall management of the regional civil service to provincial governors, the state representative under MOHA. Civil service management is also made more complex by the existence of a large number of agencies at central level: the national civil service agency, MOHA, MOF, the ministry of state apparatus reforms, and the national institute of administration. All of these organizations may be involved in establishing employment and salary conditions. Civil servants are paid according to rank, seniority, and position, with limited allowance for performance. In addition to base wages, various official allowances are paid, which makes the official salary structure complex. According to a World Bank report ${ }^{67}$, civil service management has been undermined by the opaqueness of the remuneration system, abuse of the rules and procedures, widespread patronage, and little enforcement of sanctions.

\section{Accounting and reporting on budget execution}

\section{The accounting system is capable of producing accurate in-year reports on central government budget outturns.

The new accounting system, while maintaining transaction level records on a cash basis, has been adapted to deliver financial statements in formats used for accrual based accounts. The 2004 GAFS used accrual concepts and has been published. This accounting basis is described by the authorities as "cash towards accrual basis." It is intended to introduce accrual accounting by 2008. KPPN reports on budget realization are compiled from transaction records; each spending unit reconciles its records with those of KPPNs on a monthly basis. These reports present revenues, expenditures and transfers, surplus/deficit, and financing aggregates, as compared with budget provisions. Monthly and quarterly reports on budget realization are produced within one month after the end of the month. These reports are available for internal use but are not part of a systematic budget review process. A mid-year unaudited report on budget realization is presented to the DPR in July and is

\footnotetext{
${ }^{66}$ See "Baseline Benchmarking of Indonesia’s Public Procurement System,” World Bank, July 2005.

${ }^{67}$ Civil Service Reforms at the regional level: opportunities and constraints?, World Bank, 2005.
} 
available to civil society. Since transaction level records are cash based, the balance sheet aggregates for newly acquired assets and liabilities, and derived net worth are obtained from cash transaction records (and thus valued at cost). Data on unpaid claims - accounts payable - are, however, collected from the budget users at the time of the finalization of annual accounts and reflected in the GAFS balance sheet as accounts payable.

\section{Fiscal reporting does not cover general government.}

Each level of government including central government generates fiscal reports for its legislature. While the subnational governments are required under law to submit their annual budget and reports on budget execution to the central government for information, these are not received in time from all districts. ${ }^{68}$ Consolidation of general government fiscal operations is not undertaken.

\section{There is a legal requirement for the legislature to receive a mid-year budget execution report.

The State Finances Law 17/2003 requires that the central government submit a first half-year budget realization report and projections for the second half of the year to the DPR no later than the end of the month of July. A similar provision applies for local governments with regard to mid-year reports to local legislative councils. If required, such reports may be accompanied by a draft amended budget law. In 2005, these reporting requirements had not been implemented at central government level, but the authorities expect to submit mid-year budget execution reports for fiscal year 2006 in July 2006.

\section{The audited final accounts for central government are available within one year after the end of the fiscal year.

Law 17/2003 prescribes that audited financial reports of each level of government, comprising reports on budget realization, balance sheet, cash flow statement, and notes on financial statements must be submitted to the respective legislatures not later than six months from the end of the fiscal year, beginning in 2007. At central government level, the 2004 GAFS was presented to the DPR in October 2005. The MOF expects to submit its 2005 financial statement in August 2006, and the accounts for subsequent years in June of the following year. Consolidated information on the submissions of audited financial reports of subnational governments to their respective legislature is not available.

\section{$\underline{\text { Results-oriented budgeting and reporting }}$}

54. The basis for results-oriented medium-term expenditure planning is established in regulations and is being implemented gradually. $3.2 .2 / 3.4 .3$ Government Regulation 20/2004 requires the government to specify a medium-term development plan that indicates the direction of fiscal policy. In principle, the plan embodies workplans of both the central government ministries and local governments. For central government, the programs and activities of workplans are required to be performance-based. Government Regulation 21/2004 indicates that performance-based budgets of ministries should be formulated, by linking financing to outputs and expected outcomes. The law also

${ }^{68}$ Sanctions for untimely reporting have not been applied. 
requires State ministries/institutions to evaluate performance every year on the basis of performance targets established in workplans and to conduct reviews of government programs at least once every five years. However, by 2006, only modest efforts had been made in specifying performance indicators, and progress on appraising and monitoring performance in the budget process was even more limited.

\section{Public Availability of Information}

The coverage and quality of budget and accounts documents

55. The budget documents are limited to recorded central government fiscal activities and do not include summary data on general government.

A list of documents associated with the budget approval and execution processes and their public availability is given in Appendix Table 1. Three main budget documents are presented to the DPR in August of each year: the draft budget law, the individual work plans and budgets (RKA-KLs) of central government ministries/institutions, and the financial notes. The draft budget law includes the main categories of projected revenues, the various spending programs of each ministry, and spending by function and sub-function.

The summary tables of the budget law are supported by detailed tables that disaggregate ministries' projections by internal divisional structures (echelon I units); these details are made available to the DPR on CDs. The RKA-KLs show, for each spending ministry/institution, five broad economic categories of spending. ${ }^{69}$ The financial notes provide background information on economic developments, the macroeconomic framework, its underlying assumptions, and a description of fiscal policies and budget priorities. Once the budget is adopted, all main budget documents are placed on the MOF's website http://www.djapk.depkeu.go.id.

\section{The budget documents include details of the budget estimates for the ministry of defense. \\ Defense spending, as recorded in the 2006 budget, amounted to 0.9 percent of GDP. ${ }^{70}$ In published documents, the ministry of defense's budget is shown with the same detail as other ministries: its RKA-KL shows salary, non-salary and capital expenditures of the army, navy and airforce, and 12 programs are shown under the defense functional/subfunctional classification. As noted earlier, off-budget activities are not reported, though efforts have been initiated to review these.}

Public availability of oil revenue information

57. Oil revenue flow calculations are not made publicly available nor widely shared across government agencies.

\footnotetext{
${ }^{69}$ It also includes forward estimate information on nontax revenues and expenditures per program and work unit.

${ }^{70}$ Table 8 of "Budget Statistics" http://www.djapk.depkeu.go.id/apbn/Data\%20Pokok\%20APBN\%202006\%20\%20Eng.pdf.
} 
BPMIGAS provides information on oil and gas production and cost recovery ${ }^{71}$ to DG Oil and Gas in the MOEMR. This information is also provided to the MOF oil and gas (DG MIGAS) directorate, which produces information on tax and profit sharing obligations and projections. The information on the basis of the revenue flow estimates, and their actual realization is not prepared in a form that is widely available or permits checking of prices and volumes. As a consequence, other units of government, such as BAPEKKI and BAPPENAS, do not have a fully articulated basis on which to build their projections and assess fiscal risks. Certain elements of such information, moreover, are important in terms of both internal and external accountability, including for regional governments' assessment of their oil and gas revenue share. Further clarity of revenue flows would be needed, for instance, to meet the standards being advocated for oil producing countries under the Extractive Industries Transparency Initiative (http://www.eitransparency.org).

$\underline{\text { Past and forecast fiscal data in the budget documents }}$

\section{The budget documents disclose the main fiscal aggregates for the previous fiscal year, but do not include forward budget estimates.

The previous year's budget outcome for the main categories of revenues and expenditures, and a discussion of these outcomes, is included in the budget documents. Revenue outcomes are shown by year for the previous decade. Less information is provided on expenditures. For the year prior to the budget year, the budget document includes the expenditures of the initial budget, the revised budget and the estimated outcome, but it does not show outcomes for years prior to the base year. Forward estimates, for years beyond the budget year, are not provided to the DPR.

\section{Budget treatment of off-budget fiscal activity}

\section{There are no systematic and publicly available reports of the government's contingent liabilities, tax expenditures or QFAs.}

As noted in section IA, while a number of efforts are being made to identify off-budget activities, these are not systematically reported. A systematic quantification of all contingent liabilities has not been undertaken by the government and the annual budget documents do not include an analysis of the extent of contingent liabilities. The risk management framework for PPPs is expected to monitor contingent liabilities and mechanisms for disclosure are yet to be put in place. Tax expenditures are only included as part of the revised budget, and reporting is limited to the revenue foregone from exemptions and income tax deductions accorded to state-owned enterprises. While the budget includes explicit subsidies, it does not report QFAs.

\footnotetext{
${ }^{71}$ BPMIGAS is responsible for metering oil lifting and monitoring actual costs and revenues for each contract area. BPMIGAS also approves the budget plan for each contractor. The actual outcomes are reconciled against the budget plans on a quarterly basis in reviews between BPMIGAS and each contractor and between BPMIGAS and MOHA and regional government representatives from the producing areas.
} 


\section{Publication of data on debt and financial assets}

\section{Data on central government debt are regularly published, but there are lags in} public reporting of its total debt.

Monthly and quarterly reports on total debt are available internally in the MOF. Timely information on domestic debt, classified by instrument and maturity, is published on the website of the Directorate of Government Securities Management (http://www.dmo.or.id). Aggregate information on foreign debt is published by BI in the context of SDSS on a quarterly basis. A quarterly summary of government debt data is published within three months after the end of the quarter by the BI (see http://www.bi.go.id/sdds). The DG Treasury prepares a comprehensive quarterly report on both domestic and external debt of central government. This report, which is published with about 9 month delay, ${ }^{72}$ provides data on the composition of debt by term, type of creditor, and instrument, as well as new debt issues and a forecast of maturities for the next five years. The report excludes information on local governments' debt, which is not consolidated at central level. Local government debt reports are available locally only in the districts that publish balance sheets. Data on governmentguaranteed debt and SOE debt are not made available to the public.

\section{Information on government financial assets is published annually.}

The GAFS was first published in 2004, consistent with Indonesian government accounting standards, and following efforts to prepare a first-ever balance sheet for central government. A few local governments have also begun to prepare balance sheets. These include known financial assets. The quality of data on financial assets is expected to improve over time. No in-year data on financial assets is available. For example, the on-lending and repayment activities of the RDI/RDA accounts (see paragraph 2), which are included in the annual balance sheet, are excluded from in-year monthly fiscal reports.

\section{Commitment to timely publication of fiscal data}

\section{Formal commitments for regular publication of fiscal data have been made and} advance release data calendars are announced.

Law 2003/17 requires the president to submit annual financial reports, including a budget realization statement, a balance sheet, and a cash flow statement to the DPR, and hence the public, within 6 months of year-end (applicable for the 2006 fiscal year accounts). There are no legal requirements to publish in-year fiscal data. However, Indonesia has subscribed to the IMF's Special Data Dissemination Standards (SDDS), which commits the authorities to adhering to an advance release data calendar. ${ }^{73}$ A summary of monthly central government outcomes for cash transactions is published by BI within 4 weeks after the end of the reporting period.

\footnotetext{
${ }^{72}$ For example, the second quarter report for 2005 was available on http://www.perbendaharaan.go.id in March 2006.

73 Indonesia has also completed a Data Module ROSC, which includes information on conformity with SDSS. See especially paragraph 1 of http://www.imf.org/external/pubs/ft/scr/2005/cr05255.pdf.
} 


\section{Assurances of Integrity}

\section{$\underline{\text { Integrity of data processes }}$}

\section{Budget data, especially on oil and gas revenues, have not always been reliable and the reasons for the difference between budgeted and actual outturn for the main fiscal aggregates are not disclosed to the public.

Fiscal outturns for 2003-04 were close to targets, although both revenue and expenditure composition differed from what was projected. On the revenue side, the government's conservative oil price assumption ${ }^{74}$ used in the budget led to higher than projected oil and gas revenue realization. But optimistic assumptions, notably on gains from tax administration, led to lower non-oil and gas tax revenues than predicted. On the expenditure side, large variations were observed for fuel subsidy payments, which largely reflects the oil price assumptions used (see Table 1). The fluctuations in oil prices and changes in macroeconomic assumptions led to the adoption of two revised budgets for both 2004 and 2005. ${ }^{75}$ Efforts have recently been made to establish a clearer basis for oil price projections (using futures prices) ${ }^{76}$

Table 1. Indonesia: Central Government Operations 2003-04

\begin{tabular}{|l|c|c|c|c|}
\hline & \multicolumn{2}{|c|}{2003} & \multicolumn{2}{c|}{2004} \\
\hline & $\begin{array}{c}\text { Original } \\
\text { Budget }\end{array}$ & Outturn & $\begin{array}{c}\text { Original } \\
\text { Budget }\end{array}$ & Outturn \\
\hline & \multicolumn{3}{|c|}{ (In trillions of Rupiahs) } \\
\hline Revenue and grants & 336.2 & 336.3 & 349.9 & 407.8 \\
\hline $\begin{array}{l}\text { Of which: } \\
\text { Income tax }\end{array}$ & 120.9 & 112.6 & 134.0 & 134.9 \\
\hline Oil and gas & 14.8 & 18.8 & 13.1 & 22.9 \\
\hline Non-oil and gas & 106.1 & 93.8 & 120.9 & 112.0 \\
\hline $\begin{array}{l}\text { Of which } \\
\text { Nontax revenues }\end{array}$ & 82.0 & 99.0 & 77.1 & 126.7 \\
\hline Oil and gas & 56.2 & 61.6 & 44.0 & 85.3 \\
\hline Expenditure and net lending & 370.6 & 373.5 & 374.3 & 436.4 \\
\hline $\begin{array}{l}\text { Of which: } \\
\text { Subsidies }\end{array}$ & 25.5 & 39.9 & 26.3 & 85.5 \\
\hline $\begin{array}{l}\text { Of which } \\
\text { Transfers to regions and } \\
\text { revenue sharing }\end{array}$ & 116.9 & 120.7 & 119.0 & 129.7 \\
\hline Overall balance & -34.4 & -37.3 & -24.4 & -28.6 \\
\hline Sources: Authorities and IMF staff. & \multicolumn{3}{|}{} \\
\hline
\end{tabular}

\footnotetext{
${ }^{74}$ The budget used to consistently include a low oil price so as to limit DAU transfers to provinces.

${ }^{75}$ Preliminary numbers for 2005 indicate that a higher than expected oil price and a low execution rate on capital expenditures and goods and services will lead to a high variance between budgeted and actual outturns.

${ }^{76}$ The budget use futures oil price of US\$57 a barrel in the 2006 budget (consistent with World Economic Outlook projections) and an oil lifting assumption of $1.05 \mathrm{mbpd}$. The latter assumption appears optimistic in light of the recent decline in production and the production number reported in 2005 by DGMIGAS (oil lifting of about $0.9 \mathrm{mbpd}$ for 2005).
} 


\section{Statements on accounting policy are included in the final accounts} documents.

The GAFS contains a full statement of government accounting policy. Annual central government accounts for the year 2004 were prepared under new government accounting standards (2005). ${ }^{77}$ Initial (first) balance sheets based on the new accounting basis have been compiled by polling the stock of known assets and liabilities from government institutions. As and when new assets/liabilities are disclosed, these would be brought on future balance sheets with corresponding adjustments to net worth. The accounting basis does not meet international standards of full accrual based accounting. However, the introduction of balance sheet items represents a significant step forward, which will both allow clearer treatment of asset and liability accounts and pave the way for future reforms. The main limiting factors for full implementation of the new standards are: (i) the absence of a comprehensive unit register identifying all general government institutions; and (ii) extrabudgetary activities and QFAs currently outside the purview of the MOF. The new standards apply to all levels of government. A few subnational governments have also applied these standards; others should migrate progressively over the next several years. Technical capacity constraints limit the pace at which these reforms can be implemented at all levels of government.

\section{The process of accounts reconciliation and fiscal reporting are not fully effective.}

4.1.3

Reconciliation of fiscal data with individual bank accounts with balances is done effectively and regularly at MOF. However, the aggregate reconciliation of monetary and fiscal accounts between MOF and BI is undertaken only once a year, three to four months after the end of the fiscal year. Discrepancies in classification of some government accounts in the books of MOF and BI may potentially lead to significant statistical discrepancies. ${ }^{78}$

\section{Independent oversight}

\section{The supreme audit institution (BPK) is independent of the executive, and its legal basis is being further strengthened.

The 1945 Constitution (as amended) establishes an independent supreme audit board that investigates the management and accountability of state finances, and submits its investigations to the DPR. The Constitution also outlines BPK's governance structure, namely that the members of the BPK are chosen by the DPR and formally appointed by the president. The leadership of the BPK shall be elected by the members (Article 23). BPK is

\footnotetext{
${ }^{77}$ The elements of the accounting policies are: cash basis for recognition of revenue, spending, and financing in the report on budget realization, and accrual basis for recognition of assets, liabilities, and net worth in the balance sheet. Assets are recorded at historical cost or at reasonable cost where historical cost is not available. Liabilities are recorded in terms of cash expected to be paid to meet them.

${ }^{78}$ For the most part, government accounts are defined in the same way as in monetary statistics, but some discrepancies may arise because of the unclear treatment of certain extrabudgetary funds, such as the Investment Fund. For example, a large discrepancy was found prior to the reconciliation in 2004 because of the investment fund account. The statistical discrepancy for 2005 monetary and fiscal data was initially found to be about 0.8 percent of GDP. The authorities have indicated that, from 2006 onwards, reconciliation will be done every quarter.
} 
currently governed by two laws: Law 5/1973 concerning the BPK and Law 15/2004 on Audit of State Finance Management and Responsibility, which specifies the scope of BPK's activities. In June 2006, the 1973 law was being revised with a view to bringing the law in line with the constitutional amendments of 2002 (which strengthened the operational, managerial and financial independence of BPK) and other recent laws that impact on the external audit function, including the State Finances Law and new decentralization laws.

\section{BPK's statutory audit mandate extends to all components of state finances at all levels of government.

Law 15/2004, together with Law 17/2003 (State Finance Law) prescribes the coverage of BPK's mandate, which comprehensively encompasses all state financial operations. BPK is required to audit the financial accounts of the state budget, regional budgets, state-owned and regional-owned enterprises, the BI, and other state institutions such as the Public Service Board. Law 17/2003 requires BPK's reports to be included in the accountability reports that the president and the governors, heads of provinces, district and cities for local government budgets submit to their respective legislatures within six months after the end of the fiscal year in question. BPK's jurisdiction over fiscal operations of foundations, cooperatives, and trust funds is still being established. Extra-budgetary funds like RDI, RDA, and the housing fund have been subject to specific audits. Subnational budgets have not been audited satisfactorily. Foundations are not yet being included in the audit program, though the longterm intention is that their government activities are included in the state budget.

68. Although BPK reports are published, there are no institutional arrangements at the legislature for systematic follow-up of audit findings.

Besides submitting audit reports to the DPR Budget Committee and the sectoral commissions of the legislature, copies of reports are provided to the attorney general, the police, and the Anti-Corruption Commission. BPK reports are available to the public after their submission to parliament. However, the Budget Committee of parliament itself does not report on the findings and there are no regular public hearings to discuss individual ministry accounts.

\section{A substantial strengthening of audit capacity is required for BPK to adequately fulfill its functions.

BPK is authorized to conduct three types of audits, namely: (i) financial audits, which provide the basis for an opinion on the fairness of financial information presented in financial statements and reports; (ii) performance audits, which assess the economy and efficiency of state financial resources and the effectiveness of government programs; and (iii) special purpose audits, which address specific areas of concern outside of the scope of financial and performance audits such as financially related audits, investigative audits, and audits of internal control systems. BPK's mission statement and strategic goals are clearly stated on its website, http://www.bpk.go.id. Currently BPK has around 2200 staff including support staff spread over headquarters and 14 regional offices. This is considered inadequate for covering all levels of governments, SOEs, and other institutions. The need to upgrade staff skills and further augment staffing is acknowledged by BPK management. In 2006, drawing upon higher budget allocation, the salaries of BPK's auditors were increased. 
70. Macroeconomic models and assumptions underlying the budget are discussed with external agencies, but there is no systematic independent scrutiny.

Independent macroeconomic projections are prepared by non-government economic institutes and universities and discussions are held with these, as well as with international agencies. No systematic mechanism has been established for external scrutiny of the government's budgetary projections by such bodies.

\section{The national statistics office is provided with adequate legislative assurance of} independence.

BPS is a non-departmental government institution directly responsible to the president. As noted in the Data ROSC for Indonesia published in July $2005,{ }^{79}$ safeguards of the independence of statistical compilers are provided in the Statistics Law 16/1997. GFS compilers are in practice free to choose methodologies and appropriate data sources.

The Data ROSC also reports that staff exhibit a high degree of professionalism in their work.

${ }^{79} \mathrm{See}$ http://www.imf.org/external/pubs/ft/scr/2005/cr05255.pdf 


\section{IMF STAFF COMMENTARY}

72. Indonesia has taken impressive steps in recent years to establish a sound legal and administrative framework for fiscal management, which has helped improve transparency. Key elements of financial legislation are the Law 17/2003 on State Finances, the Law 1/2004 on State Treasury, and the Law 15/2004 on State Audit. The enactment of these laws has considerably clarified the budget process, established a budget classification broadly consistent with international standards, and prescribed clear rules governing the management of transactions, assets, and debts at all levels of government. Amendments to the audit law, now being considered by Parliament will further clarify and strengthen the role of BPK.

73. A number of initiatives are underway that will improve fiscal transparency. Good progress is being made in establishing an operational TSA, a central government annual financial statement embracing accrual principles has been audited and published, and the elements of a uniform, nationwide, broadly GFS-consistent accounting classification are being established. The various reforms have the potential to establish a comprehensive fiscal management system covering all elements of general government. In turn, once an effective fiscal information and management system is in place, the tools to tackle issues like fighting corruption and improving flows of fiscal information between central and subnational governments will be greatly enhanced.

74. Much remains to be done, however, and it will take time to attain high standards in every element of the fiscal transparency code. The authorities generally recognize and openly discuss the major transparency issues described in this report. A strategy for improving transparency and strengthening fiscal management should build on the authorities' existing reform program, including implementing recent changes in legislation, while recognizing that changing the past legacy will take time. The suggested strategy has two components:

- Deepening the reforms of the central government budgetary sector; and

- Widening the process of reform to all of general government.

The second element is more difficult and can only be implemented over the longer term. An early start, however, is essential. Delay in initiating general government reforms will only increase the difficulties later, but once begun, progress should build on the continuing success of the central government reforms.

\section{A. Deepening Reforms in the Central Government Budgetary Sector}

75. The current reforms provide a strong base, but further consolidation is required. Continuing transparency and management improvement in the central budgetary process should focus on: (i) establishing high technical standards of fiscal policy management - with a balanced effort to improve the capacity of the legislature as well as the executive; 
(ii) improving budget disclosure practices; and (iii) strengthening the integrity institutions. Suggested priority actions in these areas are described below.

\section{A stronger technical base for fiscal policy management}

\section{Fiscal policy institutional arrangements}

\section{The organization and presentation of fiscal policy formulation should be} strengthened. There is a strong case for streamlining and strengthening the organization of fiscal policy formulation within the executive branch of government. In line with its overall fiscal management responsibilities under the Law on State Finances, the MOF should progressively strengthen its role in this area. It is important for the development of a strong fiscal policy function, that the MOF should have a clear mandate and a technical capacity to address all relevant aspects of macro-fiscal policy making. Moves to establish a FPO in the MOF are thus welcome. Coordination with the other agencies involved in the process of macroeconomic policy formulation (such as BAPPENAS, BI, and BPS) should continue, but the roles of these agencies should be reviewed to limit overlapping functions. In this context, the possible long-term development of BAPPENAS ${ }^{80}$ as an independent technical body with the capacity to analyze government fiscal policies objectively, might be examined. ${ }^{81}$

77. An important role of the FPO would be to integrate fiscal risk analysis within the budget process. The FPO would undertake analysis of all fiscal risks that could affect the budget, and prepare a Fiscal Risk Statement to be included in the budget documents (see below). Operational management of debt-related risk should be administered by the proposed new DG for Debt and Risk Management. The emphasis in this area should be to set high analytical and administrative standards.

78. A parallel effort should be made to strengthen the capacity of parliament to address the technical basis for the annual budget. Parliament plays an important role in the Indonesian budget process, but it has limited access to support in addressing technical issues. The imbalance of power and technical capacity has led to changes being introduced in technical assumptions by the Parliament without an adequate basis. The budget process could be greatly strengthened by establishing a strong and independent office to provide technical support to the Parliament and avoid confusion between technical forecasts and politically determined targets. ${ }^{82}$

79. The budget's appropriation structure should be focused by organization at ministry or department level. Such a structure would enable the parliamentary commissions to

\footnotetext{
${ }^{80}$ BAPPENAS currently performs a number of roles, such as helping set broad development priorities and tackling crosscutting issues such as the recent development of a compensatory package following the reduction of the fuel subsidies.

${ }^{81}$ An analysis of the rationale, mandate, and operations of fiscal agencies is described in a forthcoming IMF publication entitled "Promoting Fiscal Discipline."

${ }^{82}$ Given the substantial involvement of Parliament in the budget process, a model based on the U.S. Congressional Budget Office, but adapted to the Indonesian environment, could be considered.
} 
devote attention to expenditure priorities for ministry programs rather than being overwhelmed by line-item provisions sought for each activity by each budget user (satker). This can be facilitated by amending Law 17/2003, which would also ensure that the early review of the budget focuses only on medium-term fiscal policy objectives, broad budget aggregates and programs for the coming year and the medium term. Provision of authority for the MOF to re-appropriate between programs under the same ministry through the annual budget law from year-to-year could be used as an interim measure.

\section{Improving transparency of tax legislation and administration}

80. Taxpayer's rights should be balanced with effective tax agency powers. The DGT should have standard enforcement powers such as the authority to: (i) require banks to provide it with information on a taxpayer's banking transactions in the context of a bona fide audit; (ii) to seize (and not just freeze) a tax debtor's bank deposits and accounts receivable without having to request the permission of the tax debtor; and (iii) use any reasonable method to determine a tax liability in cases where a taxpayer fails to submit a tax return by the statutory filing date.

81. Taxpayer's rights should be further enhanced by amending the tax laws. The laws should be strengthened to: (i) remove DGT's authority to detain taxpayers; (ii) require DGT staff to report instances of misconduct to the MOF's IG and provide sanctions for failure to do so; (iii) allow taxpayers to defer payments of a disputed tax while the case is under objection or appeal; and (iv) authorize the IG's investigations unit to access taxpayer information available to DGT for the purpose of conducting an examination of preliminary evidence of misconduct by DGT staff.

\section{Reforms should aim to reduce uncertainty for taxpayers and to improve}

governance. Uncertainty in taxation should be reduced by quickly deciding on provisions of the tax package before parliament, including on taxpayers' rights and tax agency's powers, as indicated above. Governance in tax administration can be improved by: (i) expanding the code of conduct to all tax offices and amending it so that it specifies the types of sanctions that may be applied for violating the code of conduct; (ii) designing a human resources regime that creates incentives for high productivity and non-corrupt behavior by tax officers; and (iii) strengthening the IG's special investigative unit by requiring DGT staff to report instances of misconduct to the IG and providing sanctions for failure to do so.

\section{Transparency of the oil and gas sector policies and disclosures}

83. A more transparent environment should be established for the oil and gas sector. Oil revenue remains of sufficient significance to require special attention in the fiscal accounts. The management of a declining oil resource base and increasing domestic use of gas and other alternatives requires careful consideration of the fiscal impact and effects of policies on investment. Main priorities for the sector are to:

- Increase the internal and external transparency of petroleum revenues through:

(i) improving the sharing of information between BPMIGAS, DG Oil and Gas

(MOEMR), MOF (including within its own directorates), DG Tax, and BAPPENAS; and

(ii) publishing audited annual national oil and gas accounts that cover production and 
sales volumes, average product prices realized, gross revenues, and total government revenues at a consolidated national level, or preferably, on a contract-by-contract basis.

- Increase regulatory efficiency by: (i) resolving the ambiguities that exist between the oil and gas Law 22/2001 and subsequent regulations and PSC contracts, ${ }^{83}$ and (ii) speeding up approvals and tax reimbursement for the industry.

- Publish externally audited financial accounts for Pertamina for 2003, 2004 and 2005, with a view to publishing all subsequent ones within 6 months following the end of the financial year.

- Use the non-oil fiscal balance as one of the indicators of the appropriate fiscal stance.

84. Public disclosure of oil revenue flows would enhance transparency. With respect to the first of the above points, consideration could be given to participating in the Extractive Industries Transparency Initiative, which provides a vehicle for demonstrating transparency of resource revenue flows to the international community.

\section{Restructuring extrabudgetary fund accounts and improving quality of government accounts}

\section{The standard of fund management and accounts reconciliation should be improved.} Implementing the new accounting system, including the formal recognition of asset and liability accounts, provides an opportunity to consolidate reforms of a number of extrabudgetary operations, and at the same time, to improve the formal process of reconciliation of the fiscal and monetary accounts. Key proposed actions include:

- Integrate the Investment Fund (RDI) with the main treasury account. Since RDI is no longer used to relend from repayments, there is no need to maintain separate accounts. All receipts should be transferred to the treasury main account as and when they arise. These receipts should be properly classified in government accounts as revenues (interest and penalties) and draw downs of financial assets (repayment of principal).

- Review all asset and liability accounts of government, including trust funds held on behalf of third parties (such as the housing fund). Policies on these accounts should be reexamined, and the accounting and budgeting treatment shown explicitly in both the financial statements and the budget.

- Agree on the full list of government accounts. The MOF and BI should also agree on the way that these are treated in the fiscal accounts, so as to establish a clear basis for reconciliation of the monetary and fiscal accounts. Formal reconciliations should be conducted at least quarterly.

\footnotetext{
${ }^{83}$ For example, by specifying in the tax law how the oil and gas industry should be taxed, given the existence of PSCs.
} 


\section{Improving disclosure of fiscal information to the public}

86. Improvements in accounting practices provide the opportunity to make rapid gains in disclosing quality fiscal information to the public. It is essential to ensure that information released to the public is of satisfactory quality before it is released. There is now an opportunity to launch a focused program aimed both at improving data quality and informing the public. Appendix Table 1 provides an overview assessment of the status of budget and accounts documentation and its public availability.

87. An overview Fiscal Risk Statement should be included in the budget documents. It will take time to establish high quality risk disclosure statements that meet OECD standards. Once established, such a statement should cover: macroeconomic risks, oil and gas price and security risks; infrastructure projects and associated contingent liabilities; other contingent liabilities; and implicit contingent liabilities (linked to PSOs and QFAs).

Development of such a report will require systematic improvement in administration and reporting on PSOs and associated QFAs, contingent liabilities, and infrastructure and oil sector risks.

88. A major improvement is required in reporting on SOEs. Quarterly financial statements from public enterprises should be consolidated by the MSOE and forwarded to the MOF's policy analysis unit so that it can also monitor risks that may arise from it and possible contingent liabilities. Information on quasi-fiscal activities, especially of SOEs, should be made available publicly. This information could be reported as an annex to the financial statements of the public enterprises that undertake them. ${ }^{84}$

89. Timely issuance of audited accounts to the public should be emphasized. In this context, it is important that the 2006 audited accounts of central government be ready by June 2007, in line with the law. Similarly, for subnational governments, audited accounts should be made available to the public in a timely manner.

90. An annual tax expenditure report should be regularly produced. Such a report should include a complete list of exemptions, estimates of the annual revenue loss from each tax expenditure, and a written evaluation of each tax expenditure (or type of tax expenditure) that will help policy makers to understand why each tax break was originally enacted. The publishing schedule for tax expenditures should coincide with the budget process.

91. Initial efforts on within-year fiscal reporting should focus on internal review. Monthly and quarterly reports on budget realization and government cash position, together with an analysis of emerging trends in fiscal and cash aggregates, should be prepared for review by the minister of finance, and should also be circulated among concerned DG in the

\footnotetext{
${ }^{84}$ Costing should be carefully done to ensure that the full impact of PSOs is measured. For example, the previous cost and fee approach used to calculate the compensation owed to Pertamina for its sale of domestic fuel products at regulated prices did not take into account what would have been owed if market prices were charged.
} 
MOF. Once quality is assured, reports should be made available to the public. The government's cash position at the end of each quarter should be posted on the MOF website, to provide information to all stakeholders.

92. Debt reporting should be further improved. There needs to be more detailed and regular reporting (possibly monthly) and publication of data on consolidated public debt. In the longer term, public debt data should encompass local government debt, contingent liabilities and debt accumulated by public enterprises.

\section{Strengthening integrity institutions}

93. Both internal and external audit require strengthening. The most effective strategy would be to: (i) strengthen ministerial IGs as the key internal audit bodies for central government; (ii) improve the effectiveness of Bawasdas as the internal audit entities for provinces and districts; (iii) strengthen the abilities of BPK to perform its external audit functions for all levels of government; ${ }^{85}$ and (iv) undertake intensive training for IG, Bawasdas and BPK staff, particularly in investigative and risk-based audits. The role of BPKP as an internal audit body advising the president should be reviewed, with a view to deploying some of its staff to the key internal and external audit bodies. Technical capacity of audit staff in general needs to be improved.

\section{B. Toward Comprehensive General Government Transparency}

94. Extending fiscal transparency and management principles to general government is a long-term goal, but immediate action is needed. As noted in section I, at least one province has begun adopting advanced fiscal management practices. There is a need to take bold action at the center to promote dissemination of these activities more widely and to establish stronger mechanisms of coordination. The process of reviewing foundations and reducing other off-budget activities should also continue to receive sustained attention. Major efforts are required to improve coordination among the many entities involved. The MOF should establish an outreach process to make other agencies fully aware of the principles of transparency and financial management that are being applied by the central government.

\section{Clarifying intergovernmental responsibilities and subnational reporting}

95. The mechanism for coordinating fiscal management practices in the regions needs strengthening. Consideration should be given to adopting a joint decree that establishes a high level coordination forum comprising MOF, MOHA and BAPPENAS as core members. Such a high level forum would concentrate on improving subnational fiscal reporting and formulate regulatory provisions for: enhancing policy formulation for expenditure and revenue assignments; and regional financial management. The group should meet at least

\footnotetext{
${ }^{85}$ For example, by strengthening BPK's operational, managerial and budgetary independence. A review of the relationship between the Board of Audit and BPK's operational managers may also be useful in improving BPK's effectiveness.
} 
once a month to review the current status and consider new policy initiatives. ${ }^{86}$ Key issues to be addressed by the forum would include:

- Clarifying the expenditure assignments of different levels of government, including reviewing coordination mechanisms between central government ministries and provinces/districts. The issuance of a regulation that clearly delineates expenditure responsibilities would be an immediate priority.

- Acceleration of the process of improving subnational reporting by (i) mounting a coordinated program with MOHA to promote the implementation of the GFS compatible reporting format at provincial and district level; and (ii) establishing with BI and MOHA a provisional macro-level reporting system to track the regional balances, drawing on data on transfers to the provinces and monetary survey data on regional bank balances.

- Incorporating borrowings of local public enterprises or local government guarantees as part of the debt ceilings. This would necessitate the introduction of a proper reporting system of local public enterprise operations, local government debt and guarantee provisions.

\section{Extrabudgetary activities}

\section{A similar strong sense of direction should be established with regard to the incorporation of all extrabudgetary activities in the appropriate economic sectors.} The present work on reviewing foundations should be actively supported by complementary work by BPK and KPK, and broadened to encompass all line ministries. Again, a special interagency forum with a clear agenda may be used as an appropriate vehicle. Some specific actions that could be promoted by such a group include:

- Amending the Law on Foundations to allow regular audits of foundations by BPK.

- Providing BPK with resources to speedily conduct statutory audit of the operations of all foundations and submit its report to the parliament and civil society.

- Conducting a comprehensive census of all foundations, cooperatives, and trust funds under the management of central ministries/serving government officials, with a view to determining whether these institutions: (i) use government assets or receive nontax revenues; (ii) undertake fiscal operations; and (iii) serve the public interest.

Pilot studies should be conducted on key foundations to establish the appropriate system of accountability. Once completed, the authorities could build on options being considered by MSOE to incorporate military foundations into the public sector.

\footnotetext{
${ }^{86}$ This would differ from the existing Regional Autonomy Advisory Council (DPOD), as the forum would issue directives on decentralization issues, which could then be implemented at a more technical level by DPOD.
} 


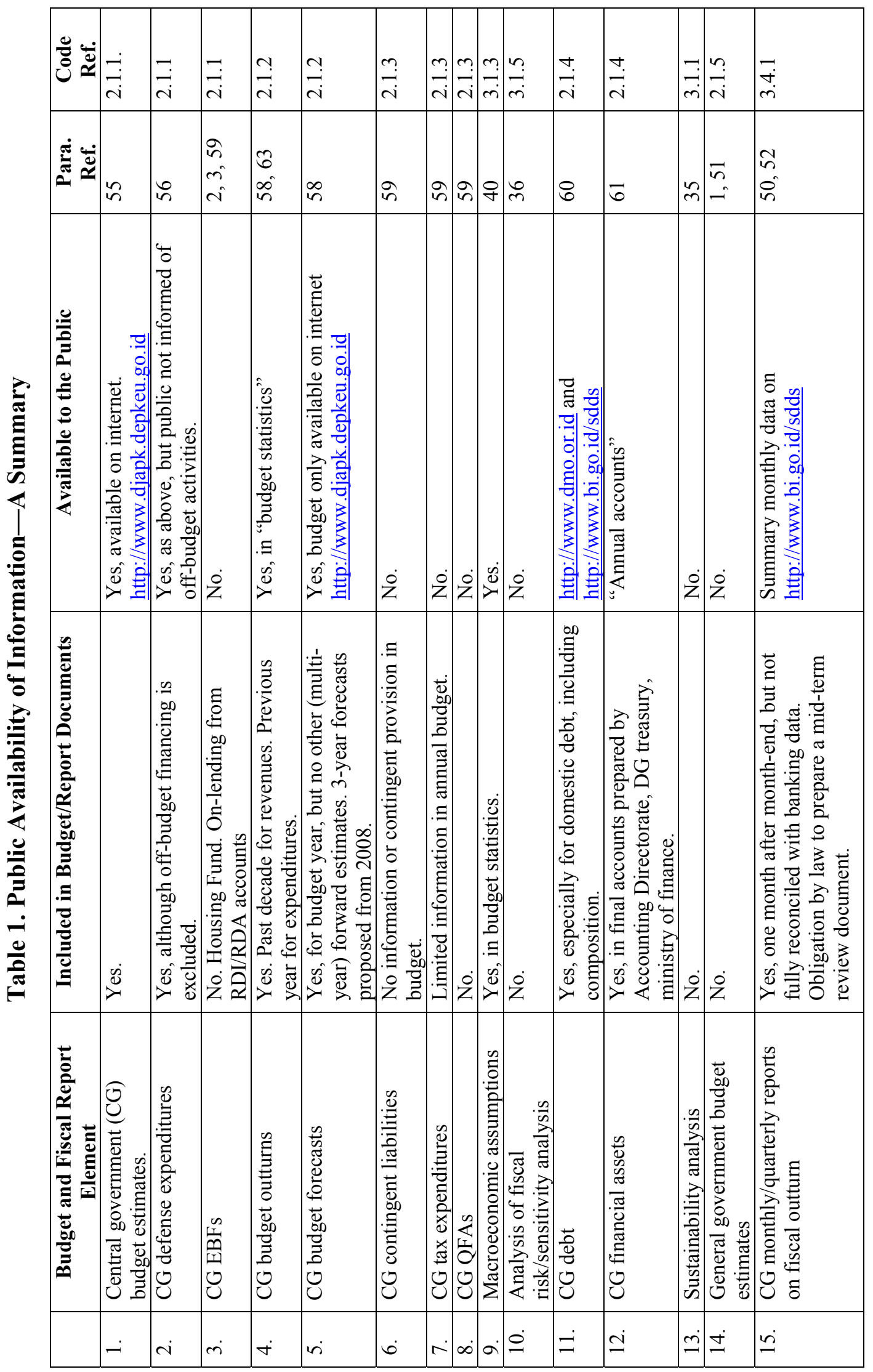

